\title{
Quorum Sensing Inhibition by Marine Bacteria
}

\author{
Anabela Borges * (iD and Manuel Simões * \\ LEPABE, Department of Chemical Engineering, Faculty of Engineering, University of Porto, \\ Rua Dr. Roberto Frias, s/n, 4200-465 Porto, Portugal \\ * Correspondence: apborges@fe.up.pt (A.B.); mvs@fe.up.pt (M.S.); \\ Tel.: +351-22-5084968 (A.B.); +351-22-5081654 (M.S.)
}

Received: 22 May 2019; Accepted: 19 July 2019; Published: 23 July 2019

\begin{abstract}
Antibiotic resistance has been increasingly reported for a wide variety of bacteria of clinical significance. This widespread problem constitutes one of the greatest challenges of the twenty-first century. Faced with this issue, clinicians and researchers have been persuaded to design novel strategies in order to try to control pathogenic bacteria. Therefore, the discovery and elucidation of the mechanisms underlying bacterial pathogenesis and intercellular communication have opened new perspectives for the development of alternative approaches. Antipathogenic and/or antivirulence therapies based on the interruption of quorum sensing pathways are one of several such promising strategies aimed at disarming rather than at eradicating bacterial pathogens during the course of colonization and infection. This review describes mechanisms of bacterial communication involved in biofilm formation. An overview of the potential of marine bacteria and their bioactive components as QS inhibitors is further provided.
\end{abstract}

Keywords: antimicrobial resistance; antipathogenic and antivirulence; quorum sensing; quorum quenching; marine bacteria; selective pressure

\section{Introduction}

Antimicrobial resistance is one of the most serious public health threats that results mostly from the selective pressure exerted by antibiotic use and abuse [1]. The overusage mistakes of the past, notably in the human medicine, veterinary, and agriculture fields, has led to the fast progression and emergence of multi-drug resistance among clinically important bacterial species [2]. Due to this growing increase of resistance, many antimicrobial agents are losing their efficiency. This problem would be of particular concern when bacteria become resistant to all different classes of antibiotics available in the market [3]. Consequently, nowadays therapeutic options for the treatment of infections have become limited or even unavailable, and there are infectious diseases that are almost untreatable by conventional antibiotic therapy [4]. According to a report of the Center for Disease Control and Prevention (CDC), bacterial resistance is still one of the most important causes of morbidity and mortality worldwide [5]. Besides, when first-line and then second-line antibiotic treatment options are limited by resistance, healthcare providers are forced to use upgraded doses and/or combined antibiotic therapy, with inherent toxicity problems for the patient and tremendous socio-economic costs. Even more worrying is the fact that the number of new antibiotics in the drug development pipeline has been continuously declining [6]. Therefore, there is an urgent need to develop strategies that can provide sustainable and long-term effectiveness against resistant pathogenic bacteria [1].

Current therapies rely in general on the ability to kill or inhibit bacterial growth, imposing thus a strong selective pressure on bacteria that can lead to the development of resistance mechanisms [7]. Newer lines of attack should target bacterial cellular processes that are responsible for pathogenesis and virulence instead of components that are essential for growth, which have garnered the name 
"antipathogenic" or "antivirulence" therapies. Unlike current antibiotics, drugs that target pathogenicity and virulence traits could constitute an advantage for the host immune system regarding bacterial adaptability and infection control. Besides, this approach can provide new means to reduce or avoid the described evolutionary pressure [8,9]. In this way, several strategies have been investigated and proposed based essentially on two master bacterial virulence systems-communication and oxidative weapons assembly systems-which coordinate the whole arsenal of virulence factors [7]. Among them, cell-to-cell communication in bacteria is crucial for their adaptation to different environments and is regulated by quorum sensing (QS) networks [7]. This signalling process is also involved in the expression of genes important to the production of virulence factors, host colonization, biofilm formation and antibiotic resistance in a number of pathogenic bacteria [10]. QS systems play a central role in the ability of bacteria to promote pathogenicity and much attention on the development of new anti-infective agents has been focused on targeting these pathways $[7,11]$. Therefore, there is a growing interest in finding ways to disrupt, block or manipulate QS signalling in bacteria $[12,13]$. The interruption of bacterial QS using other organisms, including bacteria, can offer new opportunities to understand better the molecular mechanisms that are behind communication and find alternative therapeutic strategies [13]. This ability to interfere with intercellular communication is a frequent phenomenon in the aquatic environment and is a phenomenon already identified in many marine bacteria, which has attracted the attention of the scientific community.

This study reviews bacterial QS systems and signal molecules with special emphasis on marine pathways. Considering the outstanding biological potential of marine microbial species and the lack of knowledge and exploration regarding the marine environment, the use of marine bacteria and/or their metabolites as QS inhibitors (QSIs) or antagonist is highlighted. A revised discussion of the anti-QS proficiency of marine bacteria and their metabolites will be also presented.

\section{Quorum Sensing}

QS is a process of intercellular communication, being one of the best studied types of interactions among bacterial communities in a diversity of ecological niches (e.g., terrestrial and aquatic) [14]. QS allows bacteria to cooperate or compete with each other (within a species and between species) by coordinating the expression of phenotypes and regulating physiological activities [15-17]. They include the production of secondary metabolites, toxins, antibiotics, bioluminescence, extracellular hydrolytic enzymes and exopolysaccharides (essential for bacterial adhesion and biofilm development); sporulation; bacterial conjugation; symbiosis; secretion of virulence factors; biofilm formation/differentiation; and other biological behaviors $[16,18,19]$. All of these phenotypes are useful for the colonization of different environments or hosts, establishment of disease, acquisition of nutrients and group defense [20]. QS-based interactions are dependent on the cellular density and occur through the production (signal synthase) and sensing (signal receptor) of extracellular chemical signals named autoinducers (AIs) [19]. During bacterial growth, these signaling molecules are continuously produced and released into the surrounding environment until reaching a threshold concentration, also known as "quorum level" [14]. The AIs, are then recognized by specific receptor proteins localized in the cytoplasm (Gram-negative bacteria) or in the membrane (Gram-positive bacteria), triggering a cascade of events that start the transcription of QS-regulated genes [21,22].

Different types of QS signals have been identified (Figure 1) [23-27]. Based on their structure and specific functions they are classified in three classes: (1) the acyl homoserine lactones (AHLs-AI-1) - are small molecules with a lactone ring and acyl side chain, primarily involved in QS mediation by Gram-negative bacteria [28]; (2) the autoinducer peptides (AIPs) - are short peptide chains produced in the cell, requiring membrane transport proteins to cross the cellular membrane and regulate QS in Gram-positive bacteria [29,30]; and autoinducer-2 (AI-2) — are furanone derived signal molecules (e.g., furanosyl borate diester) with combined characteristics of AHLs and AIPs, mediating QS in both Gram-negative and -positive bacteria ("universal" signaling molecules used for interspecies communication) [31]. 
AHLs - AI-1 class (Gram-negative bacteria)
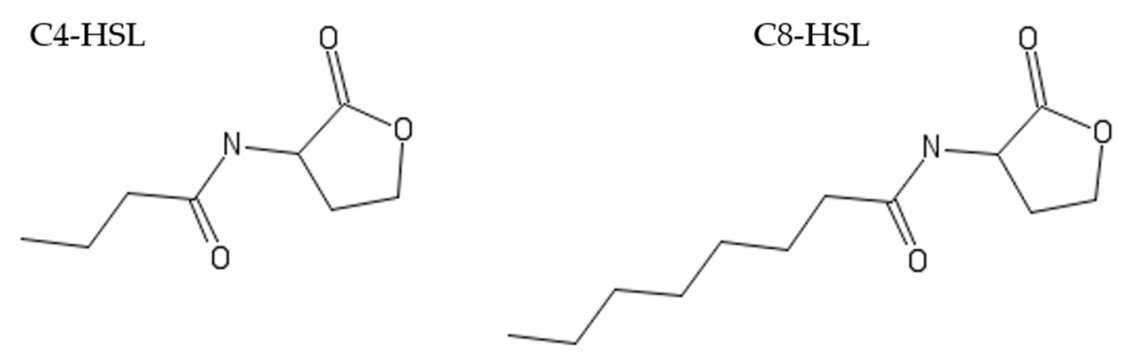

3OC6-HSL

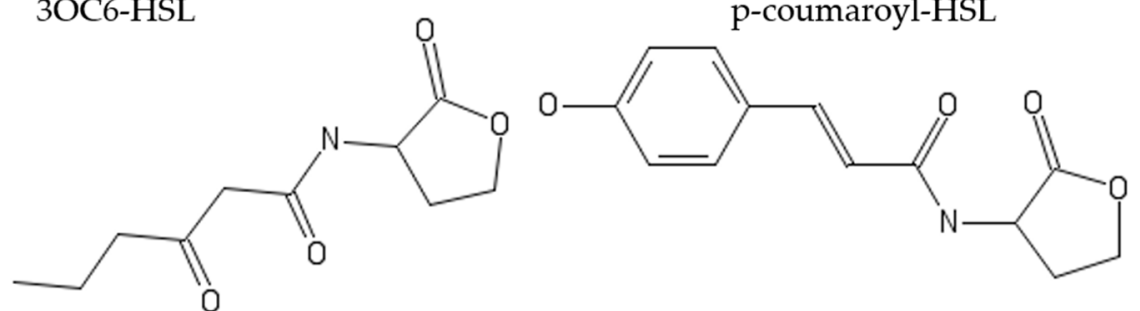

Example(s): Pseudomonas aeruginosa; Vibrio fischeri; Rhodopseudomonas palustris

AIPs class (Gram-positive bacteria)

AIP-I

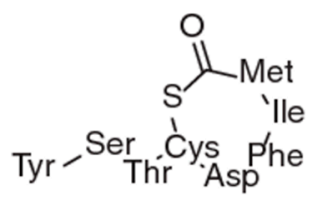

AIP-III

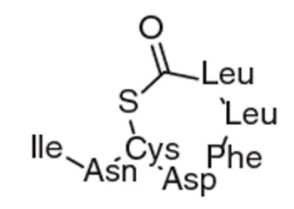

AIP-II

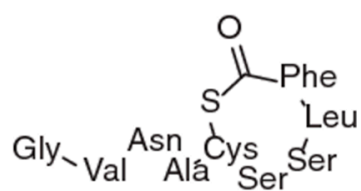

AIP-IV

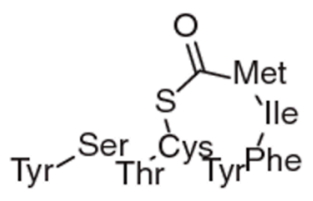

Figure 1. Cont. 
AI-2 class (Gram-negative/positive bacteria - Interspecies communication)

\section{R-THMF}

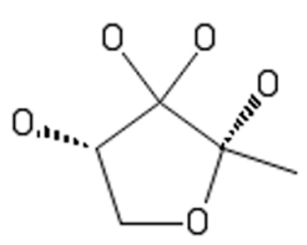

S-THMF-borate

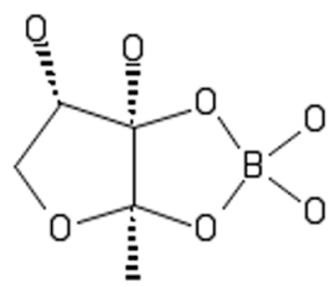

Others: DSF; PQS

DSF

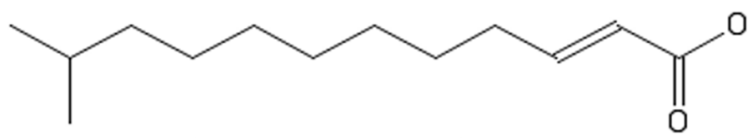

PQS

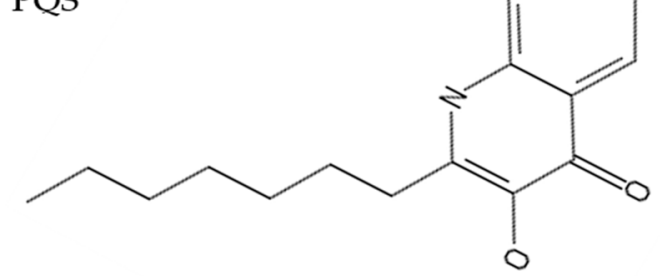

Example(s): Xanthomonas campestris; Burkholderia cenocepacia; P. aeruginosa

Example(s): Salmonella typhimurium; V. fischeri; Vibrio harveyi

Figure 1. Chemical structures of the main representative types of QS signal molecules used in the microbial regulation of QS. Note: C4-HSL-N-Butyryl-Lhomoserine lactone; C8-HSL-N-Octanoyl-L-homoserine lactone; 3OC6-HSL-N-(3-Oxohexanoyl)homoserine lactone; p-coumaroyl-HSL-N-(4-coumaroyl)-L -homoserine lactone; Non-boron containing AI-2 (R-THMF-(2R,4S)-2-methyl-2,3,3,4-tetrahydroxytetrahydrofuran); Boron containing AI-2 (S-THMF-borate(2S,4S)-2-methyl-2,3,3,4-tetrahydroxytetrahydrofuran). 
Additionally, other signaling molecules have been described [32,33] and new chemical signals continue to be discovered. Fatty acids (e.g., diffusible signal factors-DSFs; cis-2-dodecenoic acid) [34,35], Pseudomonas quinolone signal (PQS; 2-heptyl-3-hydroxy-4-quinolone) [36,37], partial ester compounds and autoinducer-3 (produced by enterohemorrhagic Escherichia coli O157:H7-involved in inter-kingdom communication and host-microbe interactions) are typical examples of these signaling molecules.

The main QS systems described are the LuxI/R-type system, the Agr system and the LuxS/AI-2 system [38]. The LuxI/R-type system utilizes AHLs as chemical signals and thus is mostly used by Gram-negative bacteria. This QS system consist of two components, the LuxI and LuxR proteins that is the AHL synthase and AHL receptor, respectively $[18,19]$. AHL-mediated QS was firstly discovered in the Gram-negative marine bacterium Vibrio fischeri, in which the regulation of the luminescence production is cell-density-dependent [21]. The Agr system is the linguistic communication commonly present in Gram-positive bacteria and uses peptide substances (AIPs) as the signal. It is a two-component QS system (RNA II and RNA III), found for example in Staphylococcus aureus [18]. LuxS/AI-2 system is involved in the synthesis of AI-2 and mediate interspecies and intraspecies interactions between Gram-positive and -negative bacteria [39]. The LuxS protein is a homodimeric metallo-enzyme that contains two identical tetrahedral metal-binding sites and can be encountered in Streptococcus genus (e.g., Streptococcus mutans, Streptococcus pyogenes, Streptococcus pneumonia and Streptococcus suis), Lactococcus lactis, Clostridium perfringens, Neisseria meningitidis, Escherichia coli, and Haemophilus influenza [39].

Some bacteria have the ability to produce and detect several AIs simultaneously. One classical example is Vibrio harveyi. This complex system was first discovered in this marine bacterium, being used as model [40]. Indeed, in V. harveyi QS network uses three AIs, depending if it is for intra-species, intra-genera or inter-species communication [19]. Another common canonical network architecture is that found in Pseudomonas spp., particularly Pseudomonas aeruginosa. In this bacterial species, there are four known QS pathways that work independently/dependently, two of them being of the LuxI/LuxR type (LasI/LasR and Rhll/RhlR systems), the quinolone-based QS system (PQS, 2-heptyl3-hydroxy-4-quinolone signal) and more recently the integrated QS system (IQS, 2-(2-hydroxyphenyl)-thiazole-4-carbaldehyde signal). These QS circuits are hierarchically arranged [41].

QS is commonly associated with functions that stimulate pathogenicity and/or virulence, but it can regulate other unrelated behaviors, particularly in the marine environment [14]. QS phenomenon have a huge impact on a variety of marine microbial systems and thus, has been receiving increasing attention from marine biologists and ecologists [14,38].

\section{Quorum Sensing in Marine Bacteria}

Numerous bacteria from different environments produce QS signaling molecules and have many QS-regulated functions [27]. Although it has been extensively demonstrated that the QS communication is very common for interactions among human pathogens, evidence has also been collected regarding the use of such mechanisms by non-pathogens such as marine bacteria [42]. In fact, most of the information on the production of QS signals by marine bacteria are about Vibrio spp. (e.g., V. fischeri, Vibrio anguillarum and V. harveyi), while other species are overlooked [42].

Marine bacteria QS signal producers can be found free-living and associated with invertebrates, sponges and diatoms, belonging manly to the $\alpha$-Proteobacteria and $\gamma$-Proteobacteria groups [42]. The genera Pseudoalteromonas, Thalassomonas, Pseudomonas, Roseobacter, Aeromonas and Vibrio are very common AIs producers in the marine habitat [43-47]. As matter of fact, Gram-negative bacteria are the prevailing bacteria in the marine environment [48].

The classes of QS signals in marine bacteria are predominantly of type I (AI-1) [e.g., AHLs ( $V$. fischeri) and $\alpha$-hydroxyketones-AHKs ( $V$. harveyi)] and II (AI-2) [e.g., furanosyl-borate diesters ( $V$. harveyi and $V$. cholera)]. These signaling molecules are known to regulate the expression of genes responsible for QS-controlled behaviors: production of bioluminescence, antibiotics, virulence factors, enzymes and biofilm development [14,42] (Figure 2). The best studied QS systems in marine microbial environments 
occur in surface-attached communities (biofilms) and depend on AHL signaling [14]. The main role of AHL-QS in marine microbial communities is related to ecologically and biogeochemically processes as well as to massive bioluminescence episodes associated with algal blooms [14]. The function of the AI-2-QS remains to be understood. However, its involvement in the regulation of the interspecies interactions in complex microbial communities has already been described [14].

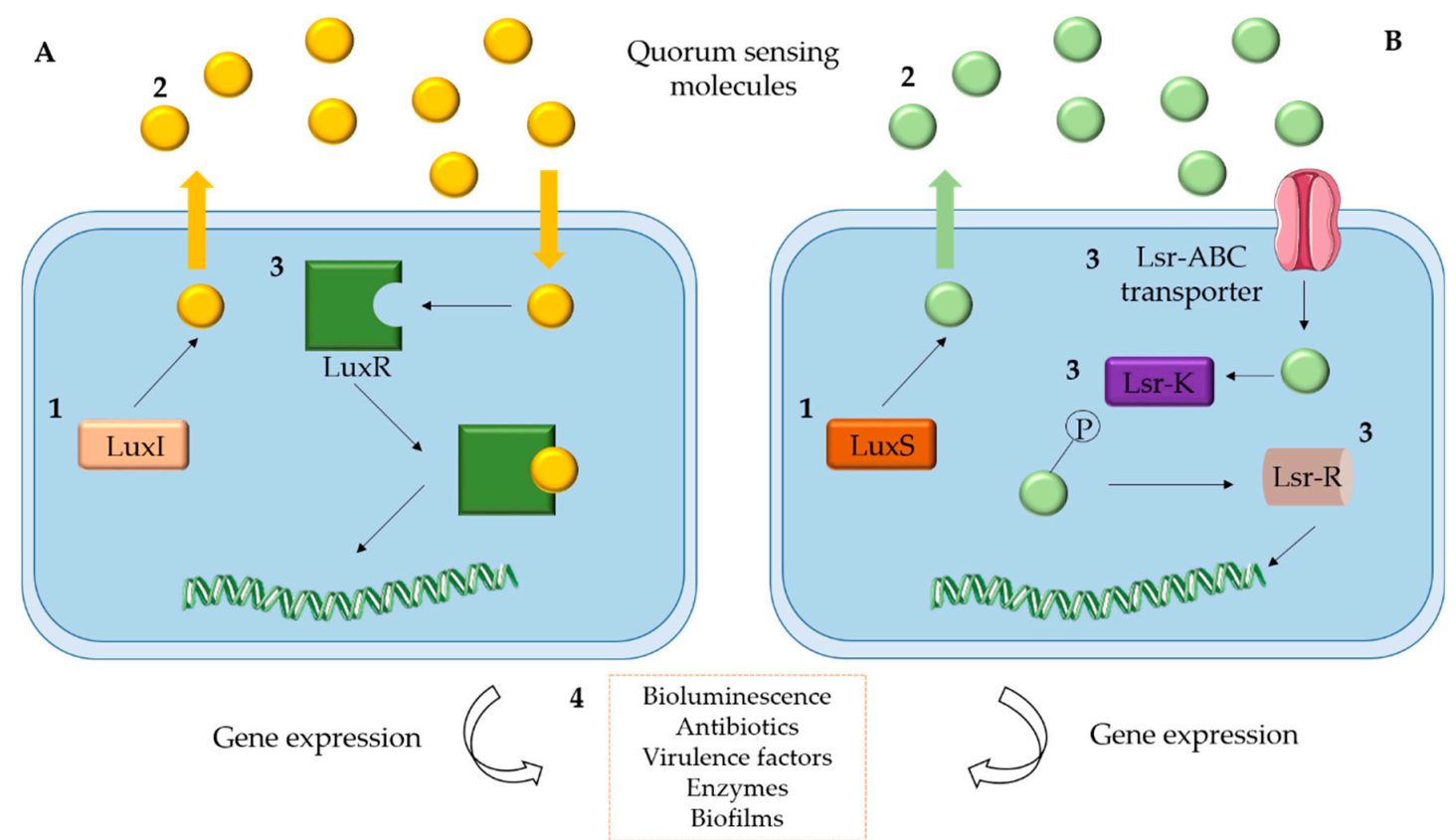

Figure 2. General scheme of the main QS mechanisms described for marine bacteria. (A) LuxI/R-type system; (B) LuxS/AI-2 system. 1-Signal synthase protein (LuxI, LuxS); 2-Autoinducers (AI-1, AI-2); 3-Response regulator protein/receptor (LuxR; Lsr-ABCKR); 4-QS regulated behaviors. Adapted from Raffa et al. [11].

\section{Quorum Sensing Inhibitors}

Undoubtedly, QS inhibition strategies, also known as "quorum quenching" (QQ), have a multifaceted value, particularly in the present scenario of rising antibiotic resistance. Such molecules are valuable to restrain or even preclude the impact of bacterial diseases in plants, animals or humans [24]. In addition to their role in infection control, the signaling molecules can also influence other microbiological features, particularly microbe-microbe interaction, host-pathogen interaction, and microbial physiology. Microorganisms can develop signal interference mechanisms to adapt to different environments, and compete for nutrients and ecological niches [49]. In a clinical perspective, the most relevant aspects of this approach are their no-lethality and versatility, as it exerts a more restricted selective pressure on bacterial survival and can act on several molecular targets [24]. Another proposed advantage is that QSIs can also favor the use of low doses of antibiotics, as they usually improve their effectiveness [10].

The interference with QS processes can be diverse, as it depends on the nature (chemical compounds, enzymes), mode of action and targets involved [27]. To disrupt QS phenomenon, three main steps can be targeted according to the QS circuit where quenching occurs and includes the signal synthase, the signal themselves and the signal receptor/transducer [27]. They can be broadly grouped into two groups, the QSIs (non-enzymatic methods) and the QQ enzymes (enzymatic methods). QSIs generally englobe compounds that are able to inactive AI synthases or receptors by competitive binding/structural modification, while QQ enzymes switch off signal transmission by signal degradation $[8,18]$. The first major QS-disrupting strategy that has been studied is the interference with the detection of the AIs and the second one is the inactivation/degradations of the signal molecules [50]. Halogenated furanones (e.g., (5Z)-4-bromo-5-(bromomethylene)-3-butyl-2(5H)-furanone) are the first 
group of QSIs encountered and were obtained from red marine algae Delisea pulchra [51]. This algae is one of the organisms that has been well studied for the production of QSIs [27]. Production of QQ enzymes that degrade QS signals have been identified in both eukaryotic and prokaryotic organisms [52]. QQ enzymes of eukaryotic origin were reported in mammals such as human $[53,54]$ and porcine [55], other vertebrates [56] and invertebrates [57,58]. The ability to quench QS signal by enzymes is extensively distributed among bacteria. Expression of QQ enzymes by $\alpha$-proteobacteria, $\beta$-proteobacteria, and the $\gamma$-proteobacteria, as well as in some Gram-positive species, has been described [59]. The bacterial species with documented QQ enzymatic activity include Bacillus sp., Bacillus thuringiensis, Bacillus. cereus, Bacillus mycoides, Bacillus anthracis, Bacillus licheniformis, Bacillus amyloliquefaciens, Bacillus megaterium, Agrobacterium tumefaciens, Arthrobacter sp., Klebsiella pneumoniae, P. aeruginosa, Pseudomonas syringae, Rastonia sp., Acinetobacter baumannii, Variovorax paradoxus, Rhodococcus erythropolis, Mycobacterium tuberculosis, Muricauda olearia, etc. [52,60-63]. The greatest part of the QQ enzymes are involved in AHL-degradation, which can be classified into three types based on their catalytic mechanism (Figure 3): AHL lactonase/paraoxonase (lactone hydrolysis), AHL acylase (amidohydrolysis) and AHL oxidase/reductase (oxidoreduction) [18,62]. Most of the described QS inhibition strategies have primarily targeted AI-1 and then AI-2. The first one is directed to only address infections by specific single species and the second permits the simultaneous inhibition and modulation of QS pathways in many species [64].

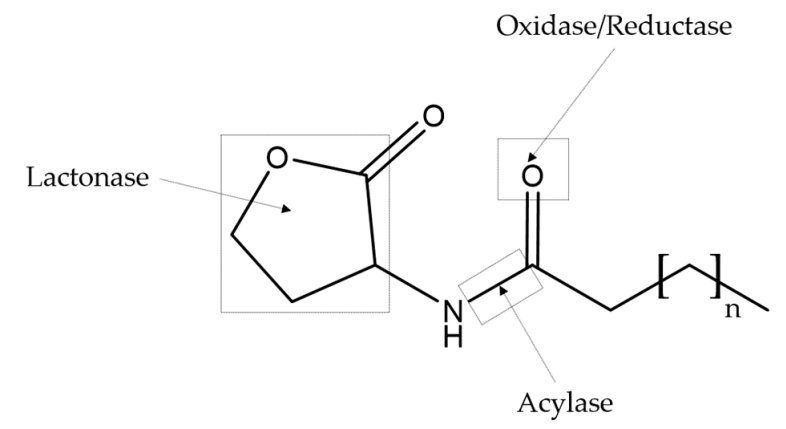

Figure 3. Schematic representation of the AHL-degrading enzyme targets. Broken lines mark position of possible cleavages of N-Butyryl-L-homoserine lactone (C4-HSL) molecule by lactonase, acylase and oxidase/reductase.

Screenings for QSIs reveal that they can be synthetic or found in nature from terrestrial, marine or freshwater ecosystems. The synthetic compounds can be tailored from exiting chemical libraries or based in a drug design approach (mostly signal mimics and furanone analogues). In nature, QSIs are generated by a wide range of living organisms, such as plants, animals, fungi or bacteria $[11,13,27,65]$. The majority of the known QSIs were predominantly identified in plants and bacteria. This could be because both plant extracts and bacteria have been more screened for these activities [27,42]. Indeed, prokaryotic byproducts is one of the strategies popularly adopted to interrupt QS mechanism. Numerous reports on bacterial metabolites with QQ activity have been published, including those from marine sources (some examples will be presented later in this review [18,22,66-68]. However, information on marine microbial species is limited when compared to their terrestrial counterparts, and many molecules remain to be identified [66].

\section{QS Inhibitors from Marine Bacteria}

Most of the available drugs in the market are natural-based formulations and this will continue to be one of the leading trends in the future [69]. Among the natural sources, the marine environment offers a plethora of resources (plants and animals) with pharmacological interest that still remain unexplored [70]. Research about the biotechnological potential of marine organisms (comprising corals, sponges, algae and bacteria) is limited and few marine-derived products are in clinical use. Examples of products include, cytarabine $\left(\right.$ Cytosar- $\mathrm{U}^{\circledR}, 1969$; Depocyt ${ }^{\circledR}$; cancer and leukemia), vidarabine 
(Vira-A ${ }^{\circledR}, 1979$; antiviral-herpes simplex virus), ziconotide (Prialt ${ }^{\circledR}, 2004$; severe chronic pain), omega-3-acid ethyl esters (Lovaza ${ }^{\circledR}, 2004$; hypertriglyceridemia), eribulin mesylate (Halaven ${ }^{\circledR}, 2010$; cancer: metastatic breast cancer), brentuximab vedotin (Adcetris ${ }^{\circledR}, 2011$; cancer: anaplastic large T-cell systemic malignant lymphoma, Hodgkin's disease), trabectedin (Yondelis ${ }^{\circledR}, 2015$; cancer: soft tissue sarcoma and ovarian cancer) and plitidepsin (Aplidin ${ }^{\circledR}, 2018$; cancer: multiple myeloma, leukemia, lymphoma) [71-75]. The first seven are currently Food and Drug Administration (FDA) approved marine-derived drugs, and the last one was approved by the European Agency [70,74,76] (Figure 4).
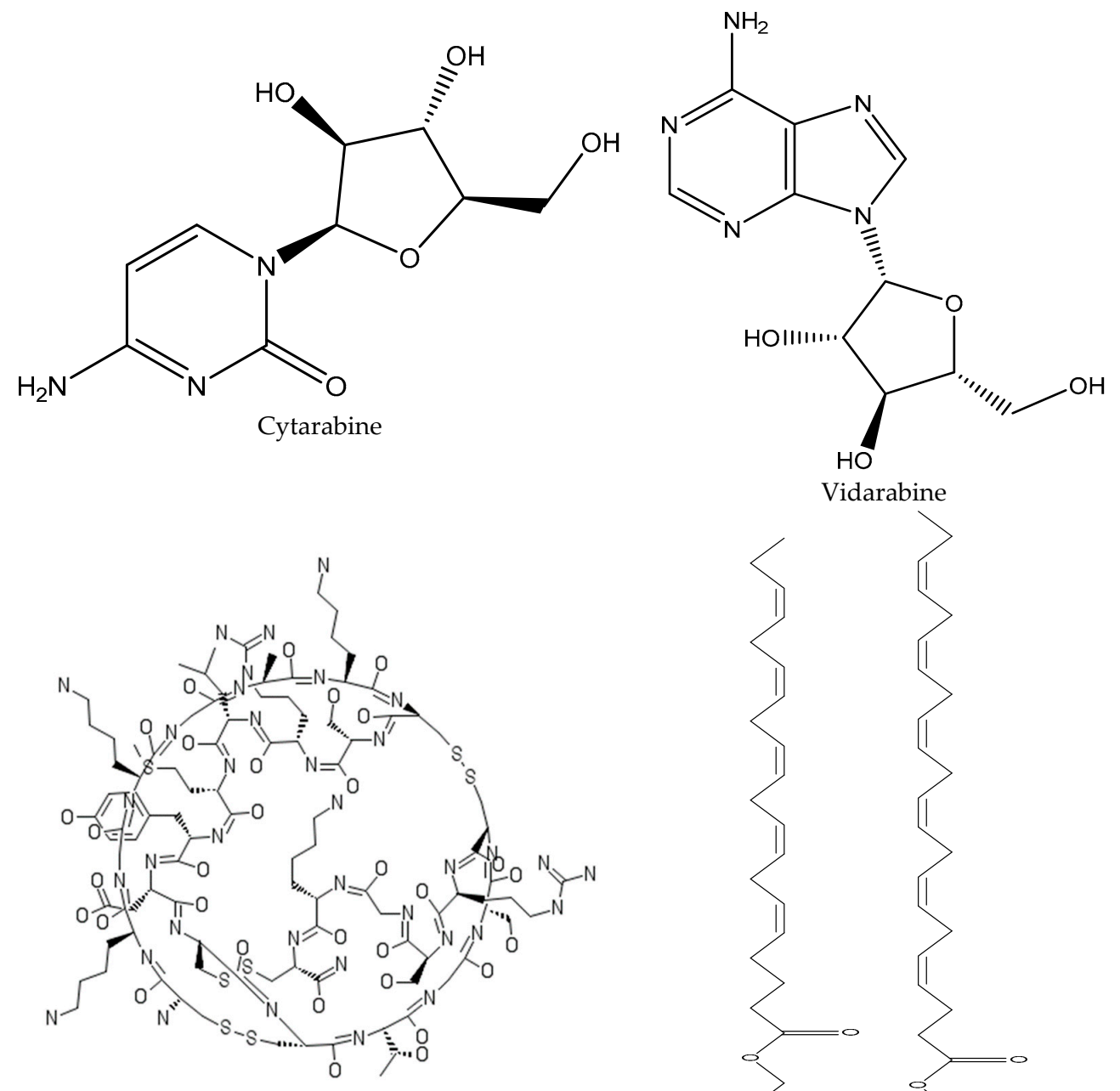

Ziconotide

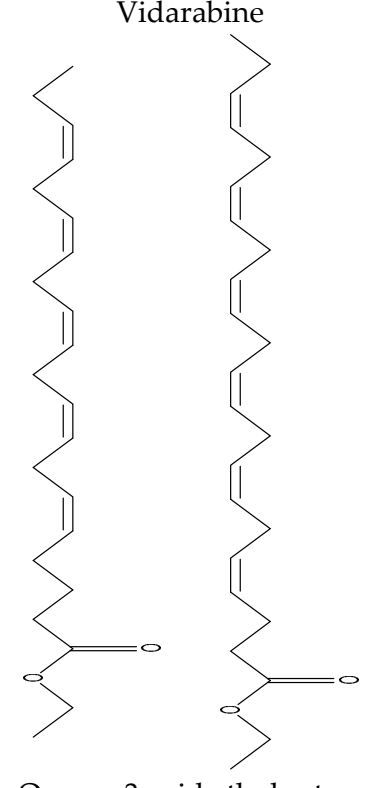

Omega-3-acid ethyl esters

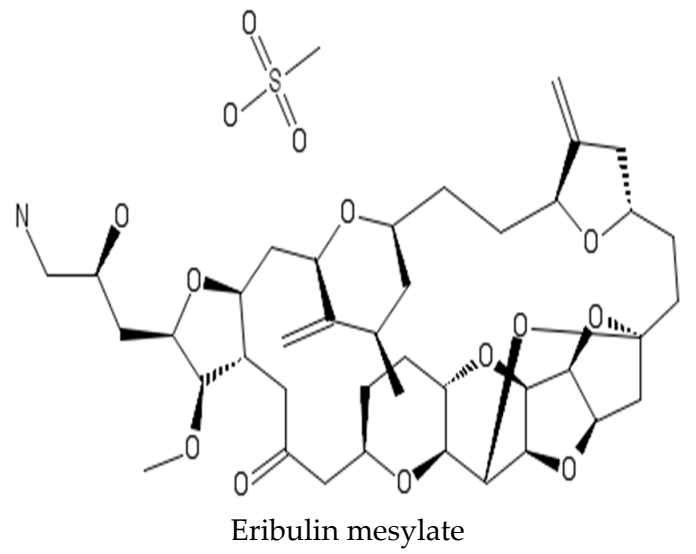

Figure 4. Cont. 


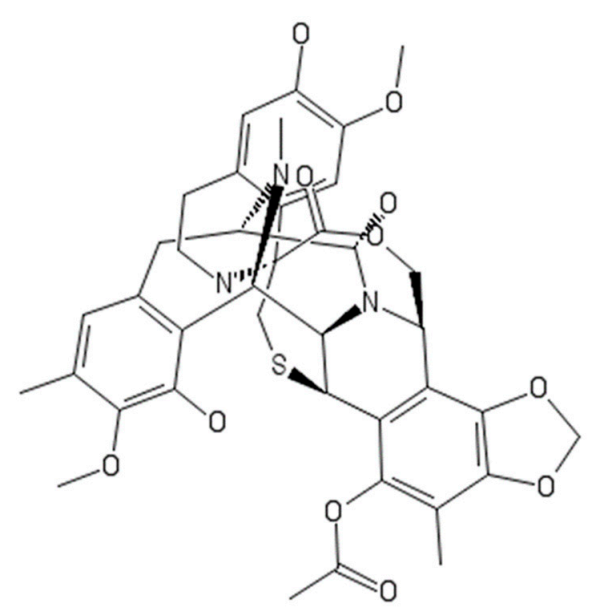

Trabectedin

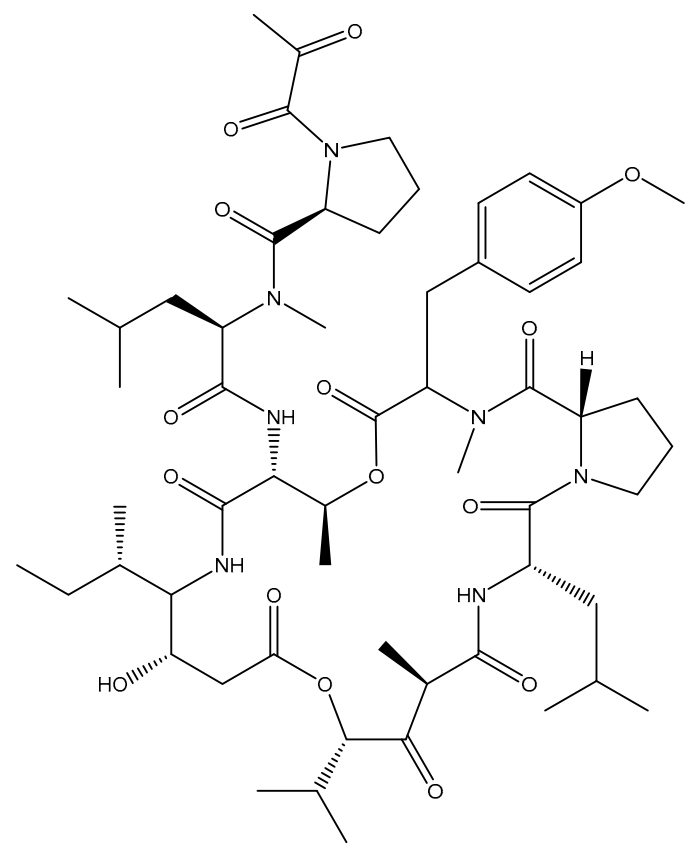

Plitidepsin

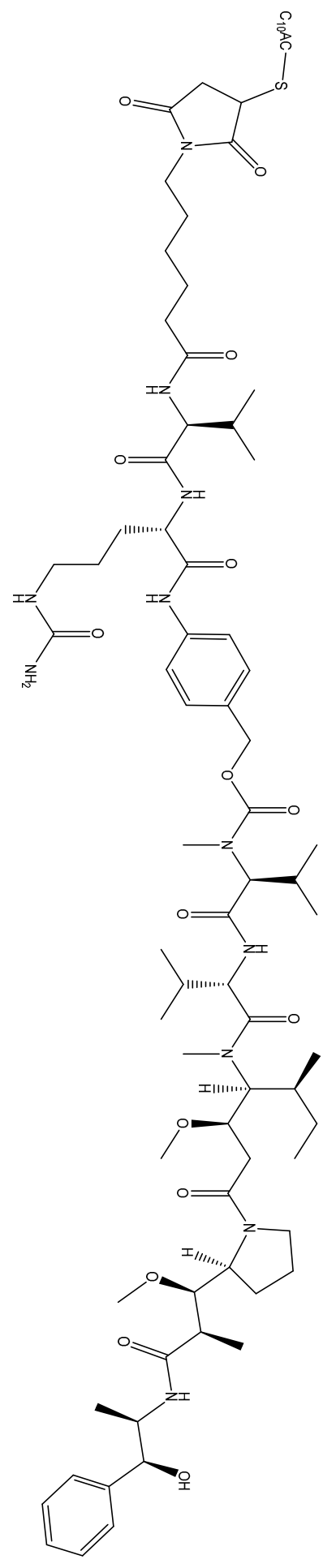

Brentuximab vedotin

Figure 4. Chemical structures of eight approved marine-derived drugs: cytarabine, vidarabine ziconotide, omega-3-acid ethyl esters, eribulin mesylate, brentuximab vedotin, trabectedin and plitidepsin.

However, there are many marine-derived compounds in the different stages of preclinical trials as well as in clinical trials (phases I, II and II), directed for diverse illnesses (antibacterial, antiparasitic, antiviral, antimalarial, anti-inflammatory, analgesic, neuroprotective and anticancer) $[70,74,76,77]$. Actually, marine organisms produce an enormous diversity of bioactive molecules with distinct chemical structures and functional features (from that found in terrestrial habitat) that provides a potential source of novel pharmaceuticals for the treatment of several diseases $[70,78,79]$. Some examples 
of new chemical entities with uncommon structures that can be found in marine bacteria are abyssomicins, salinosporamide A, and enediyne-derived cyanosporaside [80]. Abyssomicins are polycyclic polyketide-type antibiotics produced by actinomycetes of the genus Verrucosispora, with the ability to interfere with the biosynthetic pathway of the $p$-aminobenzoate/tetrahydrofolate. This is an interesting target since it occurs in diverse microorganisms and not in humans and few inhibitors of folate metabolism have been identified (e.g., sulfonamides and trimethoprim) [81]. Another recognized rare structural scaffold, also obtained from a marine actinomycete named Salinispora pacifica, is the enediyne-derived cyanosporaside. The potent DNA damaging activity and unique biosynthetic assembly is characteristic of enediyne compounds [82]. More recently, the metabolite salinosporamide A, isolated from the bacterium Salinispora tropica, was used for cancer chemotherapeutic by targeting the $\beta$ subunit of the $20 S$ proteasome. In fact, proteasome inhibitors are considered one of the most promising treatment options in cancer therapy [83].

The current focus of marine pharmacology regards the discovery of new drug candidates from marine microorganisms [76,84]. Regarding QSIs, some bacteria (e.g., Bacillus sp., Vibrio sp., P. aeruginosa) and other marine organisms (e.g., coral, sponges and algae) have both the ability to respond to QS signaling molecules of partner bacteria or to interfere and block them $[12,42,67]$. In fact, marine organisms and their associated bacteria are known to produce secondary metabolites with QS inhibitory properties (Figure 5 and Table 1). Strategies based on both QSIs and QQ enzymes seem to be widespread in the marine environment, including in marine bacteria, highlighting the importance of this biological interference for microbial processes in the ocean [14]. In the marine environment, bacteria usually adopt QS inhibition strategies to achieve competitive advantage, at least in surfaces such as biofilms and eukaryotic niches [85].

Kanagasabhapathy et al. [12] performed a screening for QSIs identification from epibiotic bacteria associated with brown algae Colpomenia sinuosa, using Serratia rubidaea JCM 14263 as an indicator organism. They showed that several of the isolated bacterial strains $(12 \%)$ were able to inhibit the production of red pigment by S. rubidaea JCM 14263 (QS regulated), suggesting its QS inhibitory activity. These isolates belong to the families Bacillaceae (Firmicutes), Pseudomonadaceae (Proteobacteria), Pseudoalteromonadaceae (Proteobacteria) and Vibrionaceae (Proteobacteria). The observed inhibitory effect is associated with the production of QSIs or QSI-like compounds as a mean of host defense and competition with other bacteria [12].

QQ activity of marine cultivable bacteria isolated from different marine samples, including diatom-dominated biofilm loosely, brown seaweed Fucus vesiculosus and the sediment of an inland fish culture tank, was investigated by Romero et al. [86]. They found anti-QS activity for some supernatants of the obtained isolates as result of violacein and light inhibition in biosensors Chromobacterium violaceum CV026/C. violaceum VIR07 and E. coli JM109 pSB1075, respectively. These authors also stated that for some of the isolates with positive results, the activity was related to an enzymatic inactivation (presence of acylases/lactonases). Active isolates were identified as belonging to the phylum/class of Alpha- and Gammaproteobacteria, Actinobacteria, Firmicutes, and Bacteroidetes.

Recently, environmental samples collected from the North Atlantic Ocean were screened with the aim of discovering compounds with QS inhibitory action, produced by the marine bacteria isolated from surface waters. The results showed that amongst the hundreds of isolates screened, some of them inhibited QS-mediated violacein production in C. violaceum ATCC12472. Identification of the bacterial strain that promoted the most significant reduction, revealed high similarity $(100 \%)$ with Rhizobium sp. The aqueous and organic extracts of Rhizobium sp. strain demonstrated ability to disrupt biofilm formation by P. aeruginosa PAO1, to downregulate the production of virulence factors (elastase and siderophore) and increase biofilm susceptibility to antibiotic kanamycin. It was also stated that the active components contained on the Rhizobium sp. supernatant were AHL analogues, specifically $\mathrm{N}$-butyryl homoserine lactone (C4-AHL), suggesting that the effects observed were due to competition with AIs produced by P. aeruginosa PAO1 [87]. 
<smiles>CC(C)C(=O)NCCc1ccccc1</smiles>

(a) - N-(2'-phenylethyl)-isobutyramide<smiles>O=C1CNC(=O)CN1</smiles>

(c)-Cyclic dipeptide<smiles>CC(C)(O)CCCCCC1C=CC(=O)O1</smiles>

(e) -5-(6-hydroxy-6-methylheptyl)furan-2(5H)-one

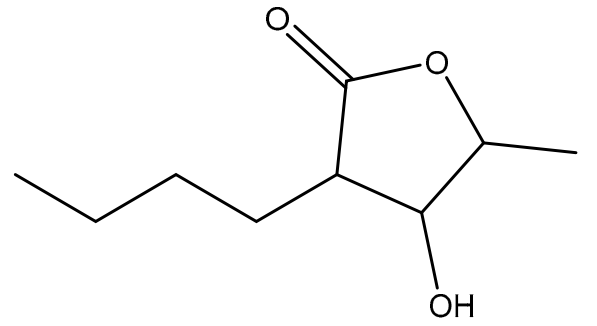

(g) -3-butyl-4-hydroxy-5-methyldihydrofuran-

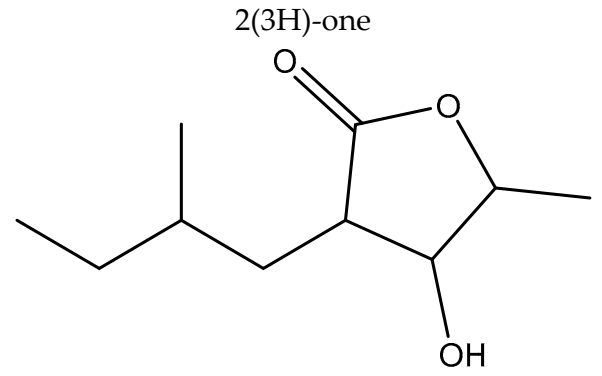

(i) - 4-hydroxy-5-methyl-3-(2methylbutyl)dihydrofuran-2(3H)-one<smiles>NCC(=O)N1CCCC1C(=O)O</smiles>

(k)-Linear dipeptides proline-glycine<smiles>CC(C)CC(=O)NCCc1ccccc1</smiles>

(b) -3-methyl-N-(2'-phenylethyl)-butyramide<smiles>CC(=O)C(C)CCCCCC1C=CC(=O)O1</smiles>

(d) -5-(6-methyl-7-oxooctyl)furan-2(5H)-one<smiles>CCC(C)(O)CCCCCC1C=CC(=O)O1</smiles>

(f) -5-(6-hydroxy-6-methyloctyl)furan-2(5H)-one

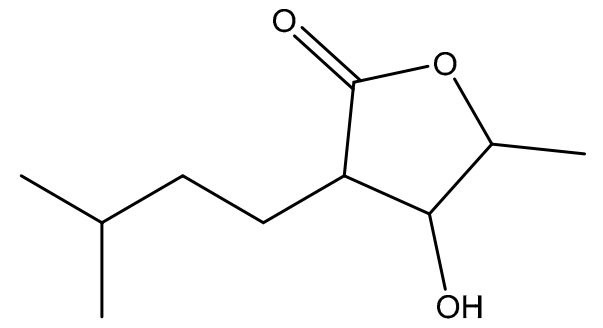

(h) -4-hydroxy-3-isopentyl-5-methyldihydrofuran2(3H)-one<smiles>O=C(O)/C=C/c1ccccc1</smiles>

(j)-Cinnamic acid<smiles>NC(=O)N1CCCC1C(=O)O</smiles>

(1)-N-amido- $\alpha$-proline

Figure 5. Cont. 


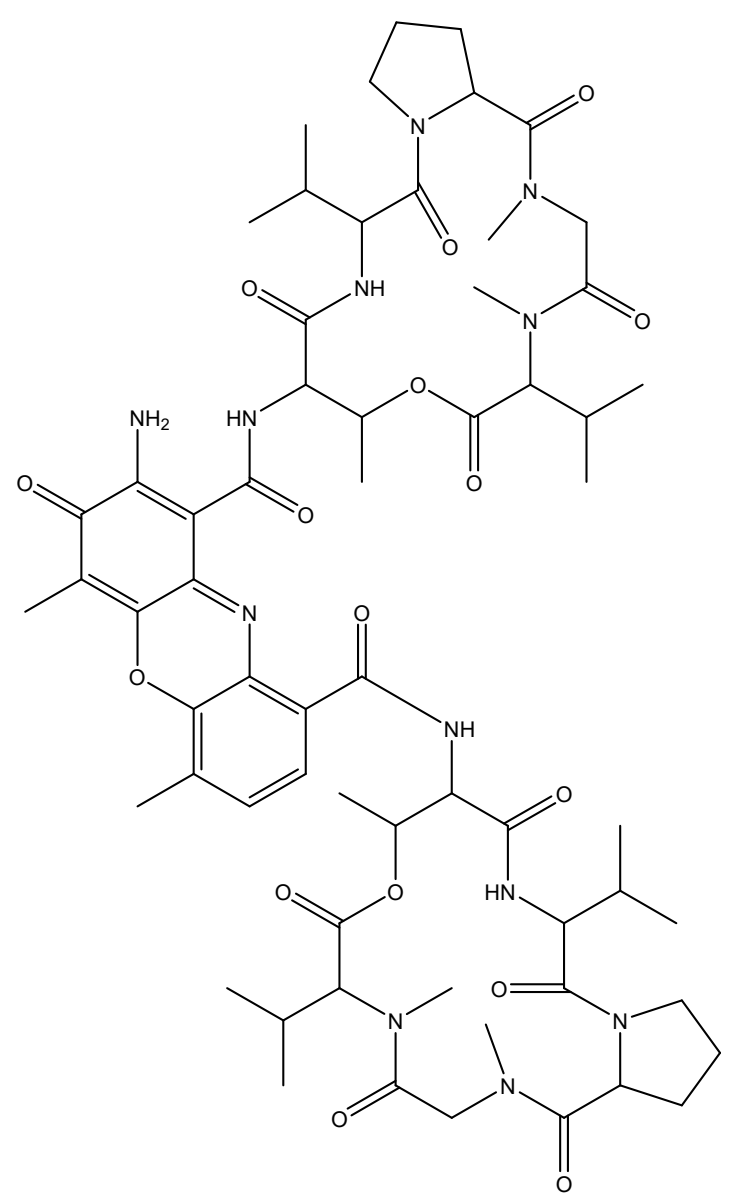

(m)-Actinomycin D<smiles>C=CC(C)(C)c1cc(/C=C/C(=O)c2ccc(O)cc2)c(OC)cc1O</smiles>

(p)-Licochalcone A

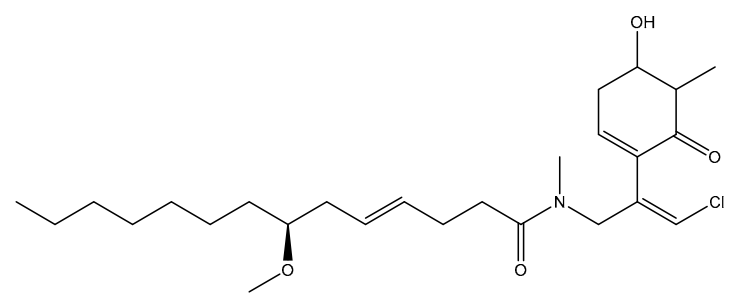

(r)-Malyngamide-L<smiles>O=C1NC(Cc2ccccc2)C(=O)N2CC(O)CC12</smiles>

(n)-Cyclic (4-hydroxy-Pro-Phe)<smiles>CC(C)CC1NC(=O)C2CCCN2C1=O</smiles>

(o)-Cyclo(Pro-Leu)/Cyclo(L-leucyl-L-prolyl)

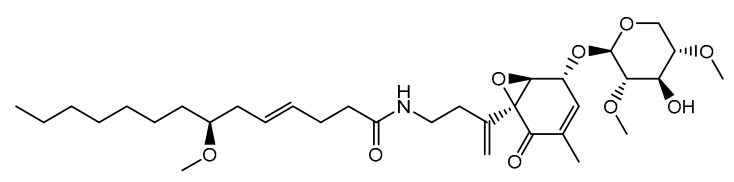

(q) - Malyngamide-J

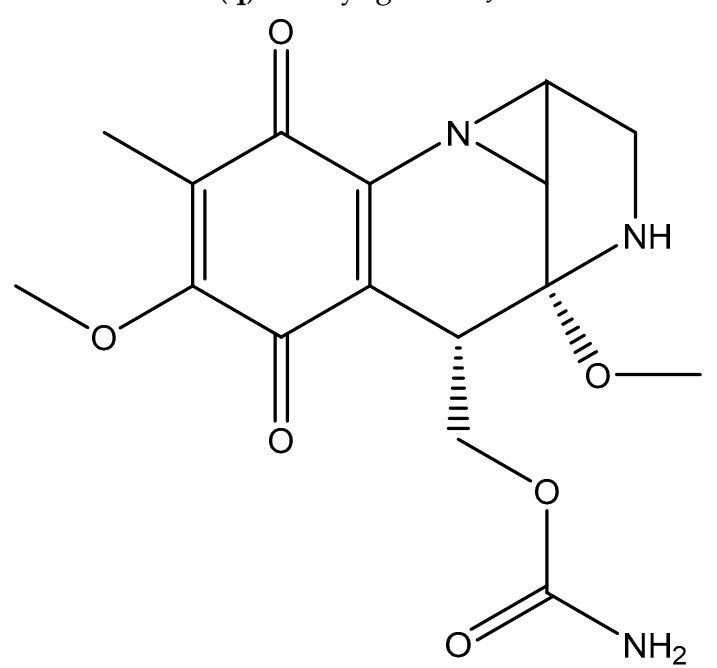

(s)-Isomitomycin A

Figure 5. Cont. 
<smiles></smiles>

(t) - Ansamitocin P-3

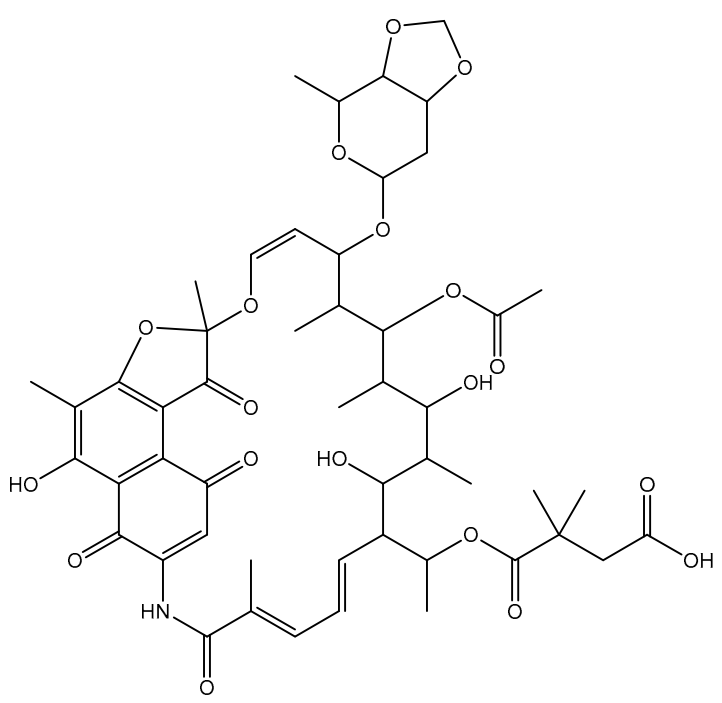

(w) - Kanglemycin A

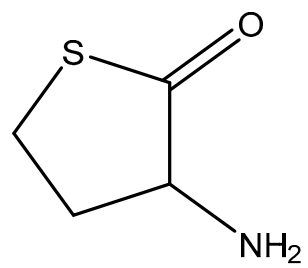

(y)-DL-homocysteine thiolactone

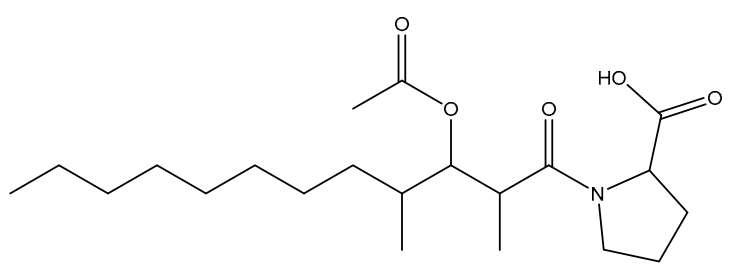

(aa)-Tumonoic acid F<smiles>C=C1CC(OC)(C(O)C(=O)NCOCC2CC(O)C(C)(C)C(CC(COC)OC)O2)OC(C)C1C</smiles>

(u)-Pederin<smiles>C[C@]1(/C=C/C=C/C=C/C(=O)O)C=C(NC(=O)/C=C/C=C/C2CCCCC2)C(=O)[C@@H]2O[C@H]21</smiles>

(v) - Nisamycin

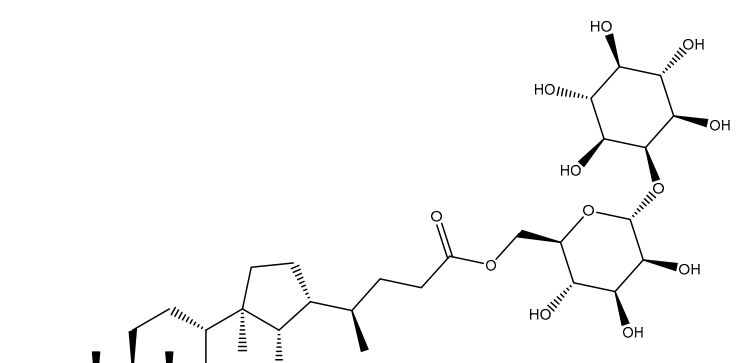

(x)-Plakohopanoid<smiles>CCCCC(C)/C=C(\C)C(O)C(C)C(=O)N1CCCC1C(=O)O</smiles>

(z) - Tumonoic acid E

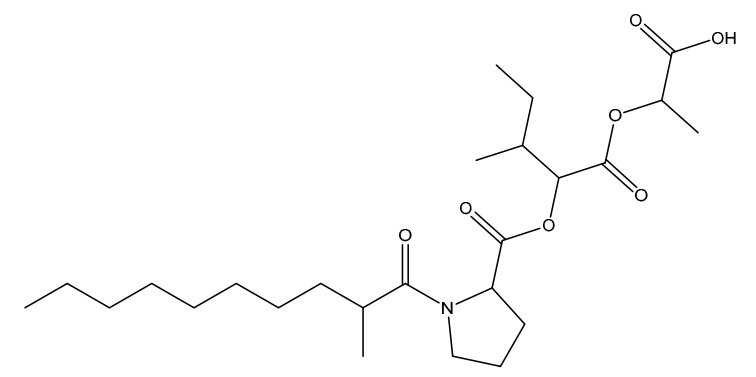

(bb)-Tumonoic acid G

Figure 5. Cont. 


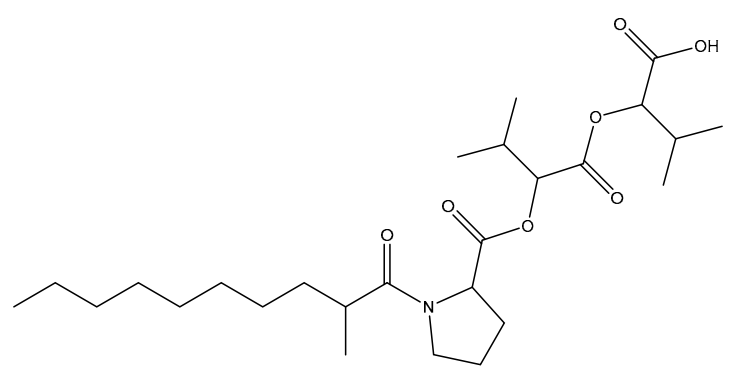

(cc)-Tumonoic acid $\mathrm{H}$

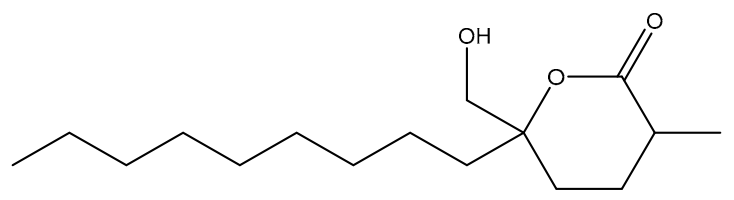

(dd)-Malyngolide

Figure 5. Chemical structures of secondary metabolites associated with bacterial QS inhibitory activities.

Teasdale and coworkers [88] reported that the Gram-positive marine bacterium Halobacillus salinus, obtained from a sea grass sample collected at the Rhode Island estuar, secrete secondary metabolites able to interfere with QS-regulated phenotypes in Gram-negative species (bioluminescence production by $V$. harveyi BB120) without causing growth inhibition. In the same way, these authors extracted and purified the active metabolites responsible for the observed effect. The active compounds identified were two phenethylamide, named N-(2'-phenylethyl)-isobutyramide (Figure 5a) and 3-methyl-N-(2'-phenylethyl)-butyramide (Figure $5 \mathrm{~b})$. These metabolites were further screened for QS inhibitory activity using QS reporter strains (V. harveyi BB120, C. violaceum CV026 and C. violaceum ATCC 12472) and positive outcomes were obtained (violacein and bioluminescence production inhibition). They also found that while considering the structural and molecular sizes similarity of the two phenethylamide and the AHL AIs, these compounds could be AHL structural mimics and compete for receptor binding. This hypothesis was corroborated for 3-methyl-N-(2'-phenylethyl)-butyramide (Figure 5b) using an E. coli JB525 sensor strain. Another study was performed in order to found more Gram-positive marine bacteria capable of producing secondary metabolites able to quench QS-controlled behaviors in Gram-negative reporter strains [89]. For this, a panel of 332 Gram-positive isolates obtained from different marine samples, including algae, invertebrates and surface sediments (collected along the Rhode Island coastline), were tested for interference with $V$. harveyi bioluminescence production, a cell signaling-regulated phenotype. They showed that 49 of the bacterial isolates inhibit bioluminescence production in $V$. harveyi without visible effects on its growth. Additionally, around 28 of the generated metabolic extracts interfered with bioluminescence production in $V$. harveyi and some of them (5 extracts) with violacein production in C. violaceum. It was also verified that most of the active bacterial isolates pertained to genus Bacillus or Halobacillus (only two belonged to Streptomyces and Micromonospora genera), and phenethylamides and a cyclic dipeptide (Figure 5c) are the two types of secondary metabolites responsible for the activities reported. The presence of the lactonase aiiA gene was detected in some of the isolates suggesting that enzymatic degradation of AHL signaling molecules could be related with the observed QS interference [89]. In another study, Nithya et al. [90] reported the production of anti-QS and antibiofilm substances by marine bacterial isolates (identified as Bacillus pumilus, Bacillus indicus, Bacillus arsenicus, Halobacillus trueperi, Ferrimonas balearica, and Marinobacter hydrocarbonoclasticus) collected from different sediment samples of Palk Bay region (India). They demonstrated that bacterial extracts reduced significantly the production of violacein in C. violaceum ATCC 12472/CV026 without growth inhibition and induced P. aeruginosa PAO1 biofilm dispersion, with disruption of the biofilm architecture. These alterations in P. aeruginosa PAO1 biofilms were found to be correlated with reductions of EPS production and the hydrophobicity index. The purification and characterization of the active principle of the most efficient crude extract of Bacillus spp. (B. pumilus) revealed the presence of phenolic groups and $\mathrm{C}-\mathrm{H}$ stretches with amine groups.

Metabolites isolated from marine-derived actinomycetes of the genus Streptomyces, collected from shallow-water sediments of the Tongyoung Bay (Korea), were considered mimics of AHL signals and classified as QS signal competitors. These metabolites contain a common lactone moiety combined with a blastmycinolactol, being included in the butenolides (Figure $5 \mathrm{~d}-\mathrm{f}$ ) and 3-hydroxy- $\gamma$-butyrolactones 
(Figure 5g-i) classes [91]. Pathogenic species of Vibrio spp. such as V. harveyi, pose serious problems in aquaculture that lead to enormous loses and thus economic implications for the producers. The problem becomes more critical when pathogenic Vibrio strains form biofilms [92]. In this sense, 88 marine actinomycetes isolated from marine sediments of South China were examined for their potential to preclude biofilms formation or to eradicate already stablished biofilms as well as their ability to inhibit QS in Vibrio species (Vibrio vulnificus V0105, V. anguillarum AN0306, and V. harveyi H). The authors attested that some extracts inhibited biofilm formation, dispersed mature biofilms or inhibited the QS system of $V$. harveyi. They also found that one of the isolates, identified as Steptomyces albus, demonstrated both the ability of attenuate biofilm formation and the activity of AIs AHLs (using A. tumefaciensWCF47 (pCF372/pCF218) indicator organism) [92]. Interesting results were also achieved with methanolic extracts of a coral associated actinomycete, identified as Streptomyces akiyoshiensis, against $S$. aureus reference strains (including MRSA) and clinical isolates, regarding antibiofilm and anti-QS activities [93]. The QS inhibitory activity was confirmed through the inhibition of the production of violacein pigment in C. violaceum ATCC 12472. Reduction in S. aureus biofilm formation were observed not only in vitro but also in vivo, which was assessed using the nematode Caenorhabditis elegans as an infection model. It is worth mentioning that no antibacterial activity was found, giving the indication that the antibiofilm effect might be associated with an interference with QS pathways. Naik and colleagues [94] investigated the occurrence of QSIs in marine sponge-derived actinomycetes (using C. violaceum CV12472 indicator strain) and tested its inhibitory activities against virulence factors (swarming, biofilm formation, pyocyanin, rhamnolipid and LasA production) that are QS-regulated in P. aeruginosa ATCC 27853. Methanolic extracts of some of the marine invertebrate-associated Streptomyces isolates demonstrated capability to both inhibit the production of violacein by C. violaceum and downregulate the QS-mediated virulence factors in P. aeruginosa. The chemical analysis of the active methanolic extracts showed the presence of the constituent's cinnamic acid (Figure 5j), linear dipeptides proline-glycine (Figure 5k) and N-amido- $\alpha$-proline (Figure 51). More recently, the anti-QS potential of marine actinomycetes obtained from samples of seawater was explored. It was found that five of the examined strains inhibited the production of violacein by C. violaceum ATCC 12472. The most prominent strain was identified as Streptomyces parvulus. Extracts of this bacterium demonstrated also ability to preclude biofilm formation by P. aeruginosa PAO1, S. aureus 95005, Micrococcus luteus 95006 and Ruegeria sp. 01008. Metabolites of S. parvulus were isolated, purified and characterized revealing to be actinomycin D (Figure 5m) and cyclic (4-hydroxy-Pro-Phe) (Figure 5n). The bioactivity of actinomycin D (Figure $5 \mathrm{~m}$ ) was analyzed and demonstrated a QS inhibition effect and a capability to inhibit prodigiosin production by Serratia proteamaculans [95].

In the study of Gutiérrez-Barranquero et al. [96], a collection of bacterial isolates obtained from marine sponges demonstrated QS inhibitory potential on three different biosensor reporter strains: Serratia marcescens SP15, C. violaceum DSM 30191 and A. tumefaciens NTL4. The bacterial isolates that inhibited the QS system of at least one biosensor strain were identified and belong to the class Gammaproteobacteria (Pseudomonas sp. strains B98C39, B98SK51b, B98SK53b, B98SK52 and B98SM8, Pseudoalteromonas sp strains J10, JC29, W3, W11 and W21, and Psychrobacter sp. strain B98C22), class Alphaproteobacteria (Paracoccus sp. JM45) and phylum Firmicutes (Bacillus sp. strains AF46, AAF47, AF52, B9853 and CC32 and Staphylococcus sp. strain B98C566). The authors verified that the observed QS inhibitory effects were non-enzymatic. Antibiofilm activity against P. aeruginosa PA14 and Bacillus subtilis CH8a was also found. Besides, P. aeruginosa PA14 virulence determinants, such as swarming/swimming motility and pyocyanin production, were suppressed. Marine bacteria (272 in total) isolated from the sponge tissues were screened for their anti-QS potential, using C. violaceum 12,472 reporter strain, and some of them revealed strong inhibitory activity (reduction of violacein production) [97]. The most prominent bacterial extracts were secondary scrutinized and permitted the selection of the highly active bacterial strain that was identified as Staphylococcus saprophyticus [98]. After extraction, isolation and identification of $S$. saprophyticus active secondary metabolites, the Cyclo(Pro-Leu) (Figure 5o) showed a moderate QS inhibition effect. 
Table 1. QS inhibition by marine bacteria and their metabolites.

\begin{tabular}{|c|c|c|c|c|}
\hline Marine Source & Bacteria and Metabolite(s) & Indicator Organism(s) & $\begin{array}{l}\text { QS Inhibitory Activity and QS Related } \\
\text { Phenotypes }\end{array}$ & Reference(s) \\
\hline Brown algae Colpomenia sinuosa & $\begin{array}{l}\text { Bacillaceae, Pseudomonadaceae, } \\
\text { Pseudoalteromonadaceae, } \\
\text { Vibrionaceae families }\end{array}$ & S. rubidaea & $\begin{array}{l}\text { Inhibition of red pigment that can be associated with } \\
\text { the production of QSIs or QS like compounds }\end{array}$ & [12] \\
\hline $\begin{array}{l}\text { Diatom-dominated biofilm loosely, } \\
\text { brown seaweed Fucus vesiculosus } \\
\text { and the sediment of an inland fish } \\
\text { culture tank }\end{array}$ & $\begin{array}{l}\text { Alpha- and Gammaproteobacteria } \\
\text { classes; Actinobacteria, Firmicutes and } \\
\text { Bacteroidetes phylum }\end{array}$ & $\begin{array}{l}\text { C. violaceum (CV026, VIR07) and } \\
\text { E. coli (JM109 pSB1075 }\end{array}$ & $\begin{array}{l}\text { Inhibition of violacein production and light emission, } \\
\text { which can be due to enzymatic inactivation }\end{array}$ & [86] \\
\hline $\begin{array}{l}\text { Surface water samples collected } \\
\text { from the North Atlantic Ocean }\end{array}$ & $\begin{array}{l}\text { Rhizobium sp; AHL analogues } \\
\text { (C4-AHL) }\end{array}$ & C. violaceum ATCC12472 & $\begin{array}{l}\text { Inhibition of violacein production. Interference with } \\
\text { P. aeruginosa biofilm formation, downregulation of } \\
\text { virulence factors production and enhanced biofilm } \\
\text { susceptibility to antibiotics. The observed outcomes } \\
\text { are attributed to AIs competition }\end{array}$ & [87] \\
\hline $\begin{array}{l}\text { Sea grass sample collected from a } \\
\text { Rhode Island estuary }\end{array}$ & $\begin{array}{l}\text { H. salinus; } \\
\text { N-(2'-phenylethyl)-isobutyramide and } \\
\text { 3-methyl-N-(2'-phenylethyl)-butyramide }\end{array}$ & $\begin{array}{l}\text { V. harveyi BB120; V. harveyi } \\
\text { BB120, C. violaceum CV026 and } \\
\text { C. violaceum ATCC } 12472\end{array}$ & $\begin{array}{l}\text { Inhibition of violacein production and luminescence } \\
\text { emission, which can be due to receptor binding } \\
\text { competition }\end{array}$ & [88] \\
\hline $\begin{array}{l}\text { Marine samples (algae, } \\
\text { invertebrates and surface } \\
\text { sediments) collected from Rhode } \\
\text { Island coastline }\end{array}$ & $\begin{array}{l}\text { Bacillus, Halobacillus, Streptomyces and } \\
\text { Micromonospora genera; } \\
\text { phenethylamides and a cyclic dipeptide }\end{array}$ & V. harveyi; C. violaceum & $\begin{array}{l}\text { Inhibition of bioluminescence emission and violacein } \\
\text { production that can be related to AHL degradation }\end{array}$ & [89] \\
\hline $\begin{array}{l}\text { Sediment samples from Palk } \\
\text { Bay region }\end{array}$ & $\begin{array}{l}\text { B. pumilus, B. indicus, B. arsenicus, } \\
\text { H. trueperi, F. balearica, } \\
\text { and M. hydrocarbonoclasticus }\end{array}$ & C. violaceum ATCC $12472 /$ CV026 & $\begin{array}{l}\text { Inhibition of violacein production; Dispersion of } \\
\text { P. aeruginosa biofilms }\end{array}$ & [90] \\
\hline $\begin{array}{l}\text { Shallow-water sediments from } \\
\text { Tongyoung Bay }\end{array}$ & $\begin{array}{l}\text { Streptomyces genus; Butenolides and } \\
\text { 3-hydroxy- } \gamma \text {-butyrolactones }\end{array}$ & - & Competition with AHL signaling molecules & [91] \\
\hline Marine sediments from South China & Actinomycetes (e.g., S. albus) & $\begin{array}{l}\text { A. tumefaciensWCF47 } \\
\text { (pCF372/pCF218) }\end{array}$ & $\begin{array}{l}\text { Inhibition of biofilm formation and biofilm } \\
\text { dispersion in } V \text {. vulnificus V0105, V. anguillarum } \\
\text { AN0306, and V. harveyi H; Decrease of AHLs activity }\end{array}$ & [92] \\
\hline Coral associated actinomycete & Actinomycetes (e.g., S. akiyoshiensis) & C. violaceum ATCC 12472 & $\begin{array}{l}\text { Inhibition of violacein production; Inhibition of } \\
\text { S. aureus (reference strains and clinical isolates) } \\
\text { biofilm formation }\end{array}$ & [93] \\
\hline $\begin{array}{l}\text { Marine sponge-derived } \\
\text { actinomycetes }\end{array}$ & $\begin{array}{l}\text { Streptomyces; Cinnamic acid, linear } \\
\text { dipeptides proline-glycine and } \\
\text { N-amido- } \alpha \text {-proline }\end{array}$ & C. violaceum CV12472 & $\begin{array}{l}\text { Inhibition of violacein production; Inference with } \\
\text { QS-regulated virulence factors in P. aeruginosa } \\
\text { ATCC } 27853\end{array}$ & [94] \\
\hline
\end{tabular}


Table 1. Cont.

\begin{tabular}{|c|c|c|c|c|}
\hline Marine Source & Bacteria and Metabolite(s) & Indicator Organism(s) & $\begin{array}{c}\text { QS Inhibitory Activity and QS Related } \\
\text { Phenotypes }\end{array}$ & Reference(s) \\
\hline $\begin{array}{l}\text { Seawater samples from } \\
\text { Lianyungang region }\end{array}$ & $\begin{array}{l}\text { Actinomycetes (e.g., S. parvulus); } \\
\text { Actinomycin D and cyclic } \\
\text { (4-hydroxy-Pro-Phe) }\end{array}$ & $\begin{array}{l}\text { C. violaceum ATCC 12472; } \\
\text { S. proteamaculans }\end{array}$ & $\begin{array}{l}\text { Inhibition of violacein production; Inhibition of } P \text {. } \\
\text { aeruginosa PAO1, S. aureus 95005, M. luteus } 95006 \text { and } \\
\text { Ruegeria sp. } 01008 \text { biofilm formation; Inhibition of } \\
\text { prodigiosin in S. proteamaculans }\end{array}$ & [95] \\
\hline Marine sponges & $\begin{array}{l}\text { Gammaproteobacteria and } \\
\text { Alphaproteobacteria classes; } \\
\text { Firmicutes phylum }\end{array}$ & $\begin{array}{l}\text { S.marcescens SP15, C. violaceum } \\
\text { DSM 30191, A. tumefaciens NTL4 }\end{array}$ & $\begin{array}{l}\text { Decrease of AHLs activity (hort-, medium- and } \\
\text { long-chain AHLs); Antibiofilm activity against } \\
\text { P. aeruginosa PA14 and B. subtilis CH8a; Inhibition of } \\
\text { swarming/swimming motility and } \\
\text { pyocyanin production }\end{array}$ & [96] \\
\hline Sponge tissues & S. saprophyticus; cyclo(Pro-Leu) & C. violaceum 12472 & Inhibition of violacein production & {$[97,98]$} \\
\hline Sponge tissues & $\begin{array}{l}\text { Proteobacteria, Firmicutes, } \\
\text { Actinobateria and Bacteroidete phylum; } \\
\text { Licochalcone A, malyngamide-J, } \\
\text { malyngamide-J, isomitomycin A, } \\
\text { ansamitocin P-3, pederin, nisamycin } \\
\text { and kanglemycin A }\end{array}$ & $\begin{array}{l}\text { V. fischeri based selector system } \\
\text { and C. violaceum CV026; } \\
\text { A. tumefaciens NT1 }\end{array}$ & $\begin{array}{l}\text { Inhibition of bioluminescence/violacein production; } \\
\text { Interference with P. aeruginosa QS-regulated } \\
\text { virulence factors (pyocyanin and protease } \\
\text { production); Inhibition of } P \text {. aeruginosa } \\
\text { biofilm formation }\end{array}$ & [99] \\
\hline Marine sponge Plakortis cf. lita & Bacterial symbionts; plakohopanoid & E. coli pSB1075 & $\begin{array}{l}\text { Inhibition of bioluminescence production; } \\
\text { Interference with P. aeruginosa QS-regulated } \\
\text { virulence factor (total protease activity) }\end{array}$ & [100] \\
\hline Mangrove rhizosphere & $\begin{array}{l}\text { B. amyloliquefaciens; } \\
\text { cyclo(L-leucyl-L-prolyl) }\end{array}$ & S. marcescens & $\begin{array}{l}\text { Inhibition of prodigiosin in S. marcescens; } \\
\text { Interference with S. marcescens QS-regulated } \\
\text { virulence factors }\end{array}$ & [101] \\
\hline Coral Pocillopora damicornis & $\begin{array}{l}\text { S. hominis; DL-homocysteine } \\
\text { thiolactone }\end{array}$ & C. violaceum ATCC 12472 & $\begin{array}{l}\text { Inhibition of violacein production; Anti-biofilm } \\
\text { activity against } P \text {. aeruginosa PAO1; Downregulation } \\
\text { of } P \text {. aeruginosa QS-related genes; QSI can be related } \\
\text { with AHL competition for the receptor }\end{array}$ & [66] \\
\hline $\begin{array}{l}\text { Extracts Cyanobacterium } \\
\text { Blennothrix cantharidosmum }\end{array}$ & Tumonoic acids (E, F, G and $\mathrm{H}$ ) & V. harveyi & Inhibition of bioluminescence production & [102] \\
\hline Florida waters samples & $\begin{array}{l}\text { Marine cyanobacteria (e.g., S. hydnoides } \\
\text { and L. majuscule); malyngolide }\end{array}$ & C. violaceum CV017 & $\begin{array}{l}\text { Inhibition of violacein production that can be } \\
\text { associated with competition for the binding site }\end{array}$ & [103] \\
\hline $\begin{array}{l}\text { Filamentous nitrogen-fixing } \\
\text { cyanobacterium }\end{array}$ & Anabaena (Nostoc) sp. PCC 7120 & - & Degradation of the AI AHL by acylase enzyme & [104] \\
\hline
\end{tabular}


In another work, extracts of 14 different species of sponges collected from the Red (Eilat, Israel) and Mediterranean (Achziv nature marine reserve) seas were screened for their anti-QS activity using two bioreporter strains (V. fischeri based selector system and C. violaceum CV026), and eleven demonstrated positive outcomes at least for one of strains. Bacterial isolates (phylum Proteobacteria, Firmicutes, Actinobateria and Bacteroidete) of six of the active sponge species were also evaluated for the QS inhibitory effects (C. violaceum CV026 and A. tumefaciens NT1) and approximately $20 \%$ revealed capability to inhibit the QS regulated violacein production. They also found that the most promising bacterial isolates interfered with P. aeruginosa PAO controlled virulence factors (pyocyanin and protease production) and with biofilm formation. The metabolic profile of these isolates were also identified and the presence of the compounds licochalcone A (Figure 5p), malyngamide-J (Figure 5q), malyngamide-L (Figure 5r), isomitomycin A (Figure 5s), ansamitocin P-3 (Figure 5t), pederin (Figure $5 \mathbf{u}$ ), nisamycin (Figure $5 v$ ) and kanglemycin A (Figure $5 w$ ) were detected. Thus, for some of the sponges the QS inhibitory activity could be related to the presence of bacterial isolates/metabolites [99]. Costantino et al. [100] studied the QS inhibitory activity of a hopanoid derivative named plakohopanoid, which was obtained from the extract of the sponge Plakortis cf. lita. The identified $\gamma$-lactone was probably secreted by bacterial symbionts of this sponge. Using the bacterial bioreporter E. coli pSB1075 (long-chain AHL-QS systems), the authors verified that plakohopanoid (Figure 5x) has high potential to inhibit QS controlled bioluminescence only at submicromolar concentrations. Moreover, this metabolite also showed ability to interfere with the virulence of the wild-type P. aeruginosa PAO1, as demonstrated by a decrease of the proteolytic activity [100].

Recently, interesting QS inhibition outcomes were achieved with the marine cyclic dipeptide -cyclo(L-leucyl-L-prolyl) (Figure 5o), secreted by a mangrove rhizosphere bacterium (B. amyloliquefaciens), against both reference and clinical isolates of $S$. marcescens, based on the inhibition of the prodigiosin production that is QS-controlled [101]. This compound exhibited an extraordinary ability to inhibit the production of other QS-regulated virulence factors (biofilm, exopolymeric substance, protease and lipase) and to affect the hydrophobicity and motility of S. marcescens. Additionally, using the C. elegans infection model the in vivo anti-adherence capability of the cyclic dipeptide -cyclo(L-leucyl-L-prolyl) (Figure 5o), as well also its ability to down regulate QS controlled virulence genes was verified. Other studies demonstrated the clinical value of mangrove rhizosphere bacteria, which include antibiofilm and antivirulence properties against important foodborne and oral pathogen (e.g., Listeria monocytogenes, S. mutans) $[105,106]$.

In order to search for new QSI, the coral Pocillopora damicornis associated bacterial isolates were examined using the indicator strain C. violaceum ATCC 12472 [66]. Positive anti-QS results were obtained for some bacterial extracts and one of them identified as Staphylococcus hominis. This extract also demonstrated anti-biofilm activity against clinical isolates of $P$. aeruginosa PAO1 and ability to down-regulate QS regulatory genes. From S. hominis extracts a compound with strong QS inhibitory activity, the DL-homocysteine thiolactone that is an analog of the AHLs, was isolated. It was hypothesized that DL-homocysteine thiolactone (Figure 5y) compete with AHL for the binding site [66].

QSIs also have been found in cyanobacteria [102-104]. For example, the cyanobacterium Blennothrix cantharidosmum produce tumonoic acids (E, F, G and H) (Figure $5 \mathrm{z}-\mathrm{cc}$ ), which are capable to inhibit bioluminescence production in V. harveyi, a phenomenon QS dependent [102]. An investigation of Dobretsov et al. [103], carried out with several extracts of marine cyanobacteria collected from Florida waters (marine and estuarine locations), demonstrated that most of them had high ability to disrupt QS as suggested by inhibition of violacein pigment production of the reporter strain C. violaceum CV017. The strongest QS inhibitory potential was obtained with extracts of Symploca hydnoides and Lyngbya majuscule, being the compound malyngolide (Figure $5 \mathrm{dd}$ ) associated to the inhibitory activity of the last one. The possible QS inhibitory mechanism of the identified QSI malyngolide is the competition for the AHL binding site of the LasR receptor. In another study, Romero et al. [104] showed that filamentous nitrogen-fixing cyanobacterium Anabaena (Nostoc) sp. PCC 7120 produced an enzyme of the acylase type that has AHL degradation activity (AHL-acylase). Together, these results give the 
indication that marine cyanobacteria can be an interesting source of QSIs, requiring further research [42]. In fact, the mode of action of their entire extracts or individual active compounds is not yet properly characterized [103].

\section{Significance and Future Perspectives}

QS plays a central role in the regulation of bacterial functions, including the expression of virulence genes in pathogenic bacteria of importance to clinical, aquaculture and agriculture sectors. Therefore, interfering with the timing of these regulatory pathways can offers new ways (different from these of antibiotics) to develop future strategies for controlling infectious diseases [42]. The manipulation of bacterial QS has attracted considerable interest from different industries (e.g., pharmaceutical, agricultural and aquaculture), as it provides new opportunities for a wide range of applications, such as therapeutic applications (humans and animals) or environmental purposes [50,61,77].

The fact that most of the studies on QS inhibition has been conducted in vitro and under laboratory conditions using essentially domesticated strains is a limitation. In order to counteract this, field investigations in conditions that mimic "real" infections (in vivo studies) are needed [22,42,61]. The lack of standardized methods for the screening of novel QSIs candidates as well as the limited knowledge on the specificity of the identified QSIs continue to be a drawback. The side effects, including toxicological, of QSIs on non-pathogenic bacteria and on the health of humans/animals, are another important criteria that has been restraining its application [107]. In fact, there are several known anti-QS compounds but they remain at the preclinical stage of the drug development process [108].

In practice, the expected application of QSIs will be alone or combined with antibiotics as potentiators/adjuvants. It has been reported that bacteria are more susceptible to antibiotics when they are combined with QSIs. This is an interesting outcome as the use of higher doses of antibiotics or antibiotics of broad-spectrum can be avoided and thus prevent eventual deleterious effects for the health [10].

Antivirulence/antipathogenic approaches such as QS disruptions are usually considered to be more attractive, as they act on pathways that are not essential for the bacterial cell growth. Unlike antibiotics, these lines of attack minimize the emergence of resistance strains providing a sustainable and long-term effectiveness. However, they need to be applied with prudence to limit the selection of more virulent strains. There is evidence that bacteria can develop several mechanism of resistance to QSIs, such as mutations in QS circuits, efflux pumps that can restrict the availability of QSI, inactivation or even modification of the target $[109,110]$. The development of resistance to QS inhibition approaches will definitely be dependent on the strategy used [61]. The use of inhibitors with multiple biological activities and non-competitive has been suggested as a priority $[109,110]$. QQ enzymes have ability to disrupt QS without the need to enter into the bacterial cells, whereby the development of resistance can be less probable [61]. Besides, the enzymes act in an independent way regarding signaling receptor (don't need to bind to a target protein), are usually considered non-toxic and can be incorporated into various matrices without being released [61]. While QS disruption affects bacterial fitness and could induce some selective pressure, affecting certain resistant bacteria, it is usually more moderate than antibiotics and spreads slowly [111].

Overall, the inhibition of QS pathways is undoubtedly promising for combatting multidrug-resistant bacteria. Future directions in this field, regarding the applicability, methods of treatment and delivery, specificity, safety, and costs need be investigated. Considering that marine bacteria and derivative compounds demonstrated high potential as QSIs, they need further attention in order to increase interest on using marine resources for advanced biofilm control. 
Author Contributions: A.B. planning and writing of the article. M.S. revising of the work for important intellectual content.

Funding: This work was the result of the projects: POCI-01-0247-FEDER-035234 (ALGAVALOR); POCI-01-0145-FEDER-030219; 0302_CVMAR_I_1_P; POCI-01-0145-FEDER-028397; POCI-01-145-FEDER-006939; POCI-01-0247-FEDER-035234; POCI-01-0247-FEDER-033298 (Laboratory for Process Engineering, Environment, Biotechnology and Energy-UID/EQU/00511/2013) funded by the European Regional Development Fund (ERDF), through COMPETE2020 - Programa Operacional Competitividade e Internacionalização (POCI) and by national funds, through FCT-Fundação para a Ciência e a Tecnologia. NORTE-01-0145-FEDER-000005LEPABE-2-ECO-INNOVATION, supported by North Portugal Regional Operational Program (NORTE 2020), under the Portugal 2020 Partnership Agreement, through the European Regional Development Fund (ERDF).

Conflicts of Interest: The authors declare no conflict of interest.

\section{References}

1. Borges, A.; Saavedra, M.J.; Simões, M. Insights on antimicrobial resistance, biofilms and the use of phytochemicals as new antimicrobial agents. Curr. Med. Chem. 2015, 22, 2590-2614. [CrossRef] [PubMed]

2. Cantas, L.; Shah, S.Q.A.; Cavaco, L.M.; Manaia, C.; Walsh, F.; Popowska, M.; Garelick, H.; Bürgmann, H.; Sørum, H. A brief multi-disciplinary review on antimicrobial resistance in medicine and its linkage to the global environmental microbiota. Front. Microbiol. 2013, 4, 1-14. [CrossRef] [PubMed]

3. Davies, J.; Davies, D. Origins and evolution of antibiotic resistance. Microbiol. Mol. Biol. Rev. 2010, 74, 417-433. [CrossRef] [PubMed]

4. French, G.L. Clinical impact and relevance of antibiotic resistance. Adv. Drug Deliv. Rev. 2005, 57, $1514-1527$. [CrossRef] [PubMed]

5. Center for Disease Control and Prevention (CDC). Antibiotic Resistance Threats in the United States; Department of Health and Human Services: Washington, DC, USA, 2013; pp. 1-113.

6. Stanton, T.B. A call for antibiotic alternatives research. Trends Microbiol. 2013, 21, 111-113. [CrossRef] [PubMed]

7. Heras, B.; Scanlon, M.J.; Martin, J.L. Targeting virulence not viability in the search for future antibacterials. Br. J. Clin. Pharmacol. 2015, 79, 208-215. [CrossRef]

8. LaSarre, B.; Federle, M.J. Exploiting quorum sensing to confuse bacterial pathogens. Microbiol. Mol. Biol. Rev. 2013, 77, 73-111. [CrossRef]

9. Mühlen, S.; Dersch, P. Anti-virulence strategies to target bacterial infections. Curr. Top. Microbiol. Immunol. 2015, 147-183.

10. Borges, A.; Abreu, A.; Dias, C.; Saavedra, M.; Borges, F.; Simões, M. New perspectives on the use of phytochemicals as an emergent strategy to control bacterial infections including biofilms. Molecules 2016, 21, 877. [CrossRef]

11. Raffa, R.B.; Iannuzzo, J.R.; Levine, D.R.; Saeid, K.K.; Schwartz, R.C.; Sucic, N.T.; Terleckyj, O.D.; Young, J.M. Bacterial communication ("quorum sensing") via ligands and receptors: A novel pharmacologic target for the design of antibiotic drugs. J. Pharmacol. Exp. Ther. 2005, 312, 417-423. [CrossRef]

12. Kanagasabhapathy, M.; Yamazaki, G.; Ishida, A.; Sasaki, H.; Nagata, S. Presence of quorum-sensing inhibitor-like compounds from bacteria isolated from the brown alga Colpomenia sinuosa. Lett. Appl. Microbiol. 2009, 49, 573-579. [CrossRef] [PubMed]

13. Bauer, W.D.; Robinson, J.B. Disruption of bacterial quorum sensing by other organisms. Curr. Opin. Biotechnol. 2002, 13, 234-237. [CrossRef]

14. Hmelo, L.R. Quorum sensing in marine microbial environments. Ann. Rev. Mar. Sci. 2017, 9, $257-281$. [CrossRef] [PubMed]

15. Waters, C.M.; Bassler, B.L. Quorum sensing: Cell-to-cell communication in bacteria. Annu. Rev. Cell Dev. Biol. 2005, 21, 319-346. [CrossRef] [PubMed]

16. Whitehead, N.A.; Barnard, A.M.L.; Slater, H.; Simpson, N.J.L.; Salmond, G.P.C. Quorum-sensing in Gram-negative bacteria. FEMS Microbiol. Rev. 2001, 25, 365-404. [CrossRef] [PubMed]

17. Abisado, R.G.; Benomar, S.; Klaus, J.R.; Dandekar, A.A.; Chandler, J.R. Bacterial quorum sensing and microbial community interactions. mBio 2018, 9, e02331-17. [CrossRef] [PubMed] 
18. Vadakkan, K.; Choudhury, A.A.; Gunasekaran, R.; Hemapriya, J.; Vijayanand, S. Quorum sensing intervened bacterial signaling: Pursuit of its cognizance and repression. J. Genet. Eng. Biotechnol. 2018, 16, $239-252$. [CrossRef] [PubMed]

19. Papenfort, K.; Bassler, B.L. Quorum sensing signal-response systems in Gram-negative bacteria. Nat. Rev. Microbiol. 2016, 14, 576. [CrossRef]

20. Jefferson, K.K. What drives bacteria to produce a biofilm? FEMS Microbiol. Lett. 2004, 236, 163-173. [CrossRef]

21. Dickschat, J.S. Quorum sensing and bacterial biofilms. Nat. Prod. Rep. 2010, 27, 343-369. [CrossRef]

22. Chen, J.; Wang, B.; Lu, Y.; Guo, Y.; Sun, J.; Wei, B.; Zhang, H.; Wang, H. Quorum sensing inhibitors from marine microorganisms and their synthetic derivatives. Mar. Drugs 2019, 17, 80. [CrossRef] [PubMed]

23. Williams, P. Quorum sensing, communication and cross-kingdom signalling in the bacterial world. Microbiology 2007, 153, 3923-3938. [CrossRef] [PubMed]

24. Uroz, S.; Dessaux, Y.; Oger, P. Quorum sensing and quorum quenching: The yin and yang of bacterial communication. Chembiochem 2009, 10, 205-216. [CrossRef] [PubMed]

25. Whiteley, M.; Diggle, S.P.; Greenberg, E.P. Progress in and promise of bacterial quorum sensing research. Nature 2017, 551, 313. [CrossRef] [PubMed]

26. Hense, B.A.; Schuster, M. Core principles of bacterial autoinducer systems. Microbiol. Mol. Biol. Rev. 2015, 79, 153-169. [CrossRef]

27. Grandclément, C.; Tannières, M.; Moréra, S.; Dessaux, Y.; Faure, D. Quorum quenching: Role in nature and applied developments. FEMS Microbiol. Rev. 2015, 40, 86-116. [CrossRef]

28. Galloway, W.R.; Hodgkinson, J.T.; Bowden, S.D.; Welch, M.; Spring, D.R. Quorum sensing in Gram-negative bacteria: Small-molecule modulation of AHL and AI-2 quorum sensing pathways. Chem. Rev. 2010, 111, 28-67. [CrossRef]

29. Sturme, M.H.; Kleerebezem, M.; Nakayama, J.; Akkermans, A.D.; Vaughan, E.E.; De Vos, W.M. Cell to cell communication by autoinducing peptides in gram-positive bacteria. Antonie Van Leeuwenhoek 2002, 81, 233-243. [CrossRef]

30. Thoendel, M.; Kavanaugh, J.S.; Flack, C.E.; Horswill, A.R. Peptide signaling in the staphylococci. Chem. Rev. 2010, 111, 117-151. [CrossRef]

31. Lowery, C.A.; Dickerson, T.J.; Janda, K.D. Interspecies and interkingdom communication mediated by bacterial quorum sensing. Chem. Soc. Rev. 2008, 37, 1337-1346. [CrossRef]

32. Hughes, D.T.; Sperandio, V. Inter-kingdom signalling: Communication between bacteria and their hosts. Nat. Rev. Micro. 2008, 6, 111-120. [CrossRef] [PubMed]

33. Sperandio, V.; Torres, A.G.; Jarvis, B.; Nataro, J.P.; Kaper, J.B. Bacteria-host communication: The language of hormones. Proc. Natl. Acad. Sci. USA 2003, 100, 8951-8956. [CrossRef] [PubMed]

34. Deng, Y.; Wu, J.e.; Eberl, L.; Zhang, L.-H. Structural and functional characterization of diffusible signal factor family quorum-sensing signals produced by members of the Burkholderia cepacia complex. Appl. Environ. Microbiol. 2010, 76, 4675-4683. [CrossRef] [PubMed]

35. Ryan, R.P.; Dow, J.M. Communication with a growing family: Diffusible signal factor (DSF) signaling in bacteria. Trends Microbiol. 2011, 19, 145-152. [CrossRef] [PubMed]

36. Lin, J.; Cheng, J.; Wang, Y.; Shen, X. The Pseudomonas quinolone signal (PQS): Not just for quorum sensing anymore. Front. Cell. Infect. Microbiol. 2018, 8, 230. [CrossRef]

37. Bala, A.; Chhibber, S.; Harjai, K. Pseudomonas quinolone signalling system: A component of quorum sensing cascade is a crucial player in the acute urinary tract infection caused by Pseudomonas aeruginosa. Int. J. Med. Microbiol. 2014, 304, 1199-1208. [CrossRef]

38. Zhou, J.; Lyu, Y.; Richlen, M.; Anderson, D.M.; Cai, Z. Quorum sensing is a language of chemical signals and plays an ecological role in algal-bacterial interactions. CRC Crit. Rev. Plant Sci. 2016, 35, 81-105. [CrossRef]

39. Wang, Y.; Wang, Y.; Sun, L.; Grenier, D.; Yi, L. The LuxS/AI-2 system of Streptococcus suis. Appl. Microbiol. Biotechnol. 2018, 102, 7231-7238. [CrossRef]

40. Miller, M.B.; Skorupski, K.; Lenz, D.H.; Taylor, R.K.; Bassler, B.L. Parallel quorum sensing systems converge to regulate virulence in Vibrio cholerae. Cell 2002, 110, 303-314. [CrossRef]

41. Lee, J.; Zhang, L. The hierarchy quorum sensing network in Pseudomonas aeruginosa. Protein Cell 2015, 6, $26-41$. [CrossRef]

42. Dobretsov, S.; Teplitski, M.; Paul, V. Mini-review: Quorum sensing in the marine environment and its relationship to biofouling. Biofouling 2009, 25, 413-427. [CrossRef] [PubMed] 
43. Gram, L.; Grossart, H.-P.; Schlingloff, A.; Kiørboe, T. Possible quorum sensing in marine snow bacteria: Production of acylated homoserine lactones by Roseobacter strains isolated from marine snow. Appl. Environ. Microbiol. 2002, 68, 4111-4116. [CrossRef] [PubMed]

44. Lynch, M.J.; Swift, S.; Kirke, D.F.; Keevil, C.W.; Dodd, C.E.; Williams, P. The regulation of biofilm development by quorum sensing in Aeromonas hydrophila. Environ. Microbiol. 2002, 4, 18-28. [CrossRef] [PubMed]

45. Mangwani, N.; Kumari, S.; Das, S. Involvement of quorum sensing genes in biofilm development and degradation of polycyclic aromatic hydrocarbons by a marine bacterium Pseudomonas aeruginosa N6P6. Appl. Microbiol. Biotechnol. 2015, 99, 10283-10297. [CrossRef] [PubMed]

46. Huang, Y.; Zeng, Y.; Yu, Z.; Zhang, J.; Feng, H.; Lin, X. In silico and experimental methods revealed highly diverse bacteria with quorum sensing and aromatics biodegradation systems-A potential broad application on bioremediation. Bioresour. Technol. 2013, 148, 311-316. [CrossRef] [PubMed]

47. Mohamed, N.M.; Cicirelli, E.M.; Kan, J.; Chen, F.; Fuqua, C.; Hill, R.T. Diversity and quorum-sensing signal production of Proteobacteria associated with marine sponges. Environ. Microbiol. 2008, 10, 75-86. [CrossRef] [PubMed]

48. Cottrell, M.T.; David, K.L. Contribution of major bacterial groups to bacterial biomass production (thymidine and leucine incorporation) in the Delaware estuary. Limnol. Oceanogr. 2003, 48, 168-178. [CrossRef]

49. Zhang, L.-H.; Dong, Y.-H. Quorum sensing and signal interference: Diverse implications. Molec. Microbiol. 2004, 53, 1563-1571. [CrossRef] [PubMed]

50. Defoirdt, T.; Sorgeloos, P.; Bossier, P. Alternatives to antibiotics for the control of bacterial disease in aquaculture. Curr. Opin. Microbiol. 2011, 14, 251-258. [CrossRef] [PubMed]

51. Manefield, M.; de Nys, R.; Naresh, K.; Roger, R.; Givskov, M.; Peter, S.; Kjelleberg, S. Evidence that halogenated furanones from Delisea pulchra inhibit acylated homoserine lactone (AHL)-mediated gene expression by displacing the AHL signal from its receptor protein. Mycobiology 1999, 145, 283-291. [CrossRef]

52. Dong, Y.-H.; Zhang, L.-H. Quorum sensing and quorum-quenching enzymes. J. Microbiol. 2005, 43, 101-109. [PubMed]

53. Chun, C.K.; Ozer, E.A.; Welsh, M.J.; Zabner, J.; Greenberg, E. Inactivation of a Pseudomonas aeruginosa quorum-sensing signal by human airway epithelia. Proc. Natl. Acad. Sci. USA 2004, 101, 3587-3590. [CrossRef] [PubMed]

54. Draganov, D.I.; Teiber, J.F.; Speelman, A.; Osawa, Y.; Sunahara, R.; La Du, B.N. Human paraoxonases (PON1, PON2, and PON3) are lactonases with overlapping and distinct substrate specificities. J. Lipid Res. 2005, 46, 1239-1247. [CrossRef] [PubMed]

55. Xu, F.; Byun, T.; Dussen, H.-J.; Duke, K.R. Degradation of N-acylhomoserine lactones, the bacterial quorum-sensing molecules, by acylase. J. Biotechnol. 2003, 101, 89-96. [CrossRef]

56. Weiland-Bräuer, N.; Fischer, M.A.; Pinnow, N.; Schmitz, R.A. Potential role of host-derived quorum quenching in modulating bacterial colonization in the moon jellyfish Aurelia aurita. Sci. Rep. 2019, 9, 34. [CrossRef] [PubMed]

57. Stoltz, D.A.; Ozer, E.A.; Taft, P.J.; Barry, M.; Liu, L.; Kiss, P.J.; Moninger, T.O.; Parsek, M.R.; Zabner, J. Drosophila are protected from Pseudomonas aeruginosa lethality by transgenic expression of paraoxonase-1. J. Clin. Investig. 2008, 118, 3123-3131. [CrossRef] [PubMed]

58. Pietschke, C.; Treitz, C.; Forêt, S.; Schultze, A.; Künzel, S.; Tholey, A.; Bosch, T.C.; Fraune, S. Host modification of a bacterial quorum-sensing signal induces a phenotypic switch in bacterial symbionts. Proc. Natl. Acad. Sci. USA 2017, 114, E8488-E8497. [CrossRef] [PubMed]

59. Czajkowski, R.; Jafra, S. Quenching of acyl-homoserine lactone-dependent quorum sensing by enzymatic disruption of signal molecules. Acta Biochim. Pol. 2009, 56, 1-16. [CrossRef]

60. Mayer, C.; Muras, A.; Romero, M.; López, M.; Tomas, M.; Otero, A. Multiple quorum quenching enzymes are active in the nosocomial pathogen Acinetobacter baumannii ATCC17978. Front. Cell. Infect. Microbiol. 2018, 8, 310. [CrossRef]

61. Bzdrenga, J.; Daudé, D.; Rémy, B.; Jacquet, P.; Plener, L.; Elias, M.; Chabrière, E. Biotechnological applications of quorum quenching enzymes. Chem. Biol. Interact. 2017, 267, 104-115. [CrossRef]

62. Chen, F.; Gao, Y.; Chen, X.; Yu, Z.; Li, X. Quorum quenching enzymes and their application in degrading signal molecules to block quorum sensing-dependent infection. Int. J. Mol. Sci. 2013, 14, 17477-17500. [CrossRef] [PubMed] 
63. Tang, K.; Su, Y.; Brackman, G.; Cui, F.; Zhang, Y.; Shi, X.; Coenye, T.; Zhang, X.-H. MomL, a novel marine-derived $\mathrm{N}$-acyl homoserine lactonase from Muricauda olearia. Appl. Environ. Microbiol. 2015, 81, 774-782. [CrossRef] [PubMed]

64. Roy, V.; Adams, B.L.; Bentley, W.E. Developing next generation antimicrobials by intercepting AI-2 mediated quorum sensing. Enzyme Microb. Technol. 2011, 49, 113-123. [CrossRef] [PubMed]

65. Kalia, V.C.; Purohit, H.J. Quenching the quorum sensing system: Potential antibacterial drug targets. Crit. Rev. Microbiol. 2011, 37, 121-140. [CrossRef] [PubMed]

66. Saurav, K.; Costantino, V.; Venturi, V.; Steindler, L. Quorum sensing inhibitors from the sea discovered using bacterial N-acyl-homoserine lactone-based biosensors. Mar. Drugs 2017, 15, 53. [CrossRef]

67. Dobretsov, S.; Abed, R.M.M.; Teplitski, M. Mini-review: Inhibition of biofouling by marine microorganisms. Biofouling 2013, 29, 423-441. [CrossRef]

68. Zhao, J.; Li, X.; Hou, X.; Quan, C.; Chen, M. Widespread existence of quorum sensing inhibitors in marine bacteria: Potential drugs to combat pathogens with novel strategies. Mar. Drugs 2019, 17, 275. [CrossRef]

69. Newman, D.J.; Cragg, G.M. Natural products as sources of new drugs over the 30 years from 1981 to 2010. J. Nat. Prod. 2012, 75, 311-335. [CrossRef]

70. Malve, H. Exploring the ocean for new drug developments: Marine pharmacology. J. Pharm. Bioallied. Sci. 2016, 8, 83-91. [CrossRef]

71. Nair, A.; Poornachand, A.; Kodisharapu, P. Ziconotide: Indications, adverse effects, and limitations in managing refractory chronic pain. Indian J. Palliat. Care 2018, 24, 118-119.

72. El-Subbagh, H.I.; Al-Badr, A.A. Chapter 2-Cytarabine. In Profiles of Drug Substances, Excipients and Related Methodology; Brittain, H.G., Ed.; Elsevier: San Diego, CA, USA; Waltham, MA, USA; London, UK, 2009; Volume 34, pp. 37-113.

73. Lee, J.-Y.; Orlikova, B.; Diederich, M. Signal transducers and activators of transcription (STAT) regulatory networks in marine organisms: From physiological observations towards marine drug discovery. Mar. Drugs 2015, 13, 4967-4984. [CrossRef] [PubMed]

74. Abadines, I.B.; Le, K.; Newman, D.J.; Glaser, K.B.; Mayer, A.M. The Marine Pharmacology and Pharmaceuticals Pipeline in 2018. FASEB J. 2019, 33, 504.

75. Katz, J.; Janik, J.E.; Younes, A. Brentuximab Vedotin (SGN-35). Clin. Cancer Res. 2011, 17, 6428. [CrossRef] [PubMed]

76. Mayer, A.M.; Glaser, K.B.; Cuevas, C.; Jacobs, R.S.; Kem, W.; Little, R.D.; McIntosh, J.M.; Newman, D.J.; Potts, B.C.; Shuster, D.E. The odyssey of marine pharmaceuticals: A current pipeline perspective. Trends Pharmacol. Sci. 2010, 31, 255-265. [CrossRef] [PubMed]

77. Skindersoe, M.E.; Ettinger-Epstein, P.; Rasmussen, T.B.; Bjarnsholt, T.; de Nys, R.; Givskov, M. Quorum sensing antagonism from marine organisms. Mar. Biotechnol. 2008, 10, 56-63. [CrossRef] [PubMed]

78. Debbab, A.; Aly, A.H.; Lin, W.H.; Proksch, P. Bioactive compounds from marine bacteria and fungi. Microb. Biotechnol. 2010, 3, 544-563. [CrossRef]

79. Romano, G.; Costantini, M.; Sansone, C.; Lauritano, C.; Ruocco, N.; Ianora, A. Marine microorganisms as a promising and sustainable source of bioactive molecules. Mar. Environ. Res. 2017, 128, 58-69. [CrossRef] [PubMed]

80. Monciardini, P.; Iorio, M.; Maffioli, S.; Sosio, M.; Donadio, S. Discovering new bioactive molecules from microbial sources. Microb. Biotechnol. 2014, 7, 209-220. [CrossRef]

81. Bister, B.; Bischoff, D.; Ströbele, M.; Riedlinger, J.; Reicke, A.; Wolter, F.; Bull, A.T.; Zähner, H.; Fiedler, H.P.; Süssmuth, R.D. Abyssomicin C-A polycyclic antibiotic from a marine Verrucosispora strain as an Inhibitor of the p-aminobenzoic acid/tetrahydrofolate biosynthesis pathway. Angew. Chem. Int. Ed. Engl. 2004, 43, 2574-2576. [CrossRef]

82. Oh, D.-C.; Williams, P.G.; Kauffman, C.A.; Jensen, P.R.; Fenical, W. Cyanosporasides A and B, chloro- and cyano-cyclopenta[a]indene glycosides from the marine actinomycete "Salinispora pacifica". Org. Lett. 2006, 8, 1021-1024. [CrossRef]

83. Gulder, T.A.; Moore, B.S. Salinosporamide natural products: Potent $20 \mathrm{~S}$ proteasome inhibitors as promising cancer chemotherapeutics. Angew. Chem. Int. Ed. Engl. 2010, 49, 9346-9367. [CrossRef] [PubMed]

84. Kijjoa, A.; Sawangwong, P. Drugs and cosmetics from the sea. Mar. Drugs 2004, 2, 73-82. [CrossRef] 
85. Romero, M.; Martin-Cuadrado, A.-B.; Otero, A. Determination of whether quorum quenching is a common activity in marine bacteria by analysis of cultivable bacteria and metagenomic sequences. Appl. Environ. Microbiol. 2012, 78, 6345-6348. [CrossRef] [PubMed]

86. Romero, M.; Martin-Cuadrado, A.-B.; Roca-Rivada, A.; Cabello, A.M.; Otero, A. Quorum quenching in cultivable bacteria from dense marine coastal microbial communities. FEMS Microbiol. Ecol. 2011, 75, $205-217$. [CrossRef] [PubMed]

87. Chang, H.; Zhou, J.; Zhu, X.; Yu, S.; Chen, L.; Jin, H.; Cai, Z. Strain identification and quorum sensing inhibition characterization of marine-derived Rhizobium sp. NAO1. R. Soc. Open Sci. 2017, 4, 170025. [CrossRef] [PubMed]

88. Teasdale, M.E.; Liu, J.; Wallace, J.; Akhlaghi, F.; Rowley, D.C. Secondary metabolites produced by the marine bacterium Halobacillus salinus that inhibit quorum sensing-controlled phenotypes in gram-negative bacteria. Appl. Environ. Microbiol. 2009, 75, 567-572. [CrossRef] [PubMed]

89. Teasdale, M.E.; Donovan, K.A.; Forschner-Dancause, S.R.; Rowley, D.C. Gram-positive marine bacteria as a potential resource for the discovery of quorum sensing inhibitors. Mar. Biotechnol. 2011, 13, 722-732. [CrossRef]

90. Nithya, C.; Begum, M.F.; Pandian, S.K. Marine bacterial isolates inhibit biofilm formation and disrupt mature biofilms of Pseudomonas aeruginosa PAO1. Appl. Microbiol. Biotechnol. 2010, 88, 341-358. [CrossRef] [PubMed]

91. Cho, K.W.; Lee, H.-S.; Rho, J.-R.; Kim, T.S.; Mo, S.J.; Shin, J. New lactone-containing metabolites from a marine-derived bacterium of the genus Streptomyces. J. Nat. Prod. 2001, 64, 664-667. [CrossRef]

92. You, J.; Xue, X.; Cao, L.; Lu, X.; Wang, J.; Zhang, L.; Zhou, S. Inhibition of Vibrio biofilm formation by a marine actinomycete strain A66. Appl. Microbiol. Biotechnol. 2007, 76, 1137-1144. [CrossRef]

93. Bakkiyaraj, D.; Karutha Pandian, S.T. In vitro and in vivo antibiofilm activity of a coral associated actinomycete against drug resistant Staphylococcus aureus biofilms. Biofouling 2010, 26, 711-717. [CrossRef] [PubMed]

94. Naik, D.; Wahidullah, S.; Meena, R. Attenuation of Pseudomonas aeruginosa virulence by marine invertebrate-derived Streptomyces sp. Lett. Appl. Microbiol. 2013, 56, 197-207. [CrossRef] [PubMed]

95. Miao, L.; Xu, J.; Yao, Z.; Jiang, Y.; Zhou, H.; Jiang, W.; Dong, K. The anti-quorum sensing activity and bioactive substance of a marine derived Streptomyces. Biotechnol. Biotechnol. Equip. 2017, 31, 1007-1015. [CrossRef]

96. Gutiérrez-Barranquero, J.A.; Reen, F.J.; Parages, M.L.; McCarthy, R.; Dobson, A.D.; O'Gara, F. Disruption of $\mathrm{N}$-acyl-homoserine lactone-specific signalling and virulence in clinical pathogens by marine sponge bacteria. Microb. Biotechnol. 2017. [CrossRef] [PubMed]

97. Ding, B.-T.; Lu, Y.-Q.; Dong, K.-M.; Wang, X.-Z.; Zhou, X.-J.; Jin, C.-L.; Miao, L. Screen for the quorum sensing inhibitory activity from marine bacterial isolates. Microbiol. China 2012, 39, 0002-0008.

98. Li, M.; Huiru, Z.; Biting, D.; Yun, J.; Wei, J.; Kunming, D. Study on the anti-quorum sensing activity of a marine bacterium Staphylococcus saprophyticus 108. BioTechnology 2013, 7, 480-487.

99. Saurav, K.; Bar-Shalom, R.; Haber, M.; Burgsdorf, I.; Oliviero, G.; Costantino, V.; Morgenstern, D.; Steindler, L. In search of alternative antibiotic drugs: Quorum-quenching activity in sponges and their bacterial isolates. Front. Microbiol. 2016, 7, 416. [CrossRef]

100. Costantino, V.; Della Sala, G.; Saurav, K.; Teta, R.; Bar-Shalom, R.; Mangoni, A.; Steindler, L. Plakofuranolactone as a quorum quenching agent from the Indonesian sponge Plakortis cf. lita. Mar. Drugs 2017, 15, 59. [CrossRef]

101. Gowrishankar, S.; Pandian, S.; Balasubramaniam, B.; Balamurugan, K. Quorum quelling efficacy of marine cyclic dipeptide -cyclo(L-leucyl-L-prolyl) against the uropathogen Serratia marcescens. Food Chem. Toxicol. 2019, 123, 326-336. [CrossRef]

102. Clark, B.R.; Engene, N.; Teasdale, M.E.; Rowley, D.C.; Matainaho, T.; Valeriote, F.A.; Gerwick, W.H. Natural products chemistry and taxonomy of the marine cyanobacterium Blennothrix cantharidosmum. J. Nat. Prod. 2008, 71, 1530-1537. [CrossRef]

103. Dobretsov, S.; Teplitski, M.; Alagely, A.; Gunasekera, S.P.; Paul, V.J. Malyngolide from the cyanobacterium Lyngbya majuscula interferes with quorum sensing circuitry. Environ. Microbiol. Rep. 2010, 2, 739-744. [CrossRef] [PubMed]

104. Romero, M.; Diggle, S.P.; Heeb, S.; Camara, M.; Otero, A. Quorum quenching activity in Anabaena sp. PCC 7120: Identification of AiiC, a novel AHL-acylase. FEMS Microbiol. Lett. 2008, 280, 73-80. [CrossRef] [PubMed] 
105. Gowrishankar, S.; Sivaranjani, M.; Kamaladevi, A.; Ravi, A.V.; Balamurugan, K.; Karutha Pandian, S. Cyclic dipeptide cyclo(l-leucyl-1-prolyl) from marine Bacillus amyloliquefaciens mitigates biofilm formation and virulence in Listeria monocytogenes. Pathog. Dis. 2016, 74, ftw017. [CrossRef] [PubMed]

106. Gowrishankar, S.; Poornima, B.; Pandian, S.K. Inhibitory efficacy of cyclo(l-leucyl-1-prolyl) from mangrove rhizosphere bacterium-Bacillus amyloliquefaciens (MMS-50) toward cariogenic properties of Streptococcus mutans. Res. Microbiol. 2014, 165, 278-289. [CrossRef] [PubMed]

107. Kalia, V.C. Quorum sensing inhibitors: An overview. Biotechnol. Adv. 2013, 31, 224-245. [CrossRef] [PubMed]

108. Pan, J.; Ren, D. Quorum sensing inhibitors: A patent overview. Expert Opin. Ther. Pat. 2009, 19, $1581-1601$. [CrossRef] [PubMed]

109. Koul, S.; Prakash, J.; Mishra, A.; Kalia, V.C. Potential emergence of multi-quorum sensing inhibitor resistant (MQSIR) bacteria. Indian J. Microbiol. 2016, 56, 1-18. [CrossRef]

110. Kalia, V.C.; Wood, T.K.; Kumar, P. Evolution of resistance to quorum-sensing inhibitors. Microb. Ecol. 2014, 68, 13-23. [CrossRef]

111. Defoirdt, T.; Boon, N.; Bossier, P. Can bacteria evolve resistance to quorum sensing disruption? PLoS Pathog. 2010, 6, e1000989. [CrossRef]

(C) 2019 by the authors. Licensee MDPI, Basel, Switzerland. This article is an open access article distributed under the terms and conditions of the Creative Commons Attribution (CC BY) license (http://creativecommons.org/licenses/by/4.0/). 